\title{
Characterizing the heterogeneity of karst critical zone and its hydrological function: an integrated approach
}

\begin{tabular}{|r|l|}
\hline Journal: & Hydrological Processes \\
\hline Manuscript ID & HYP-18-0002.R1 \\
\hline Wiley - Manuscript type: & Special issue: Water in the Critical Zone \\
\hline Complete List of Authors: & $\begin{array}{l}\text { Chen, Xi; State Key Laboratory of Hydrology-Water Resources and } \\
\text { Hydraulic Engineering, Hohai University } \\
\text { Zhang, Zhicai; Hohai University, State Key Laboratory of Hydrology-Water } \\
\text { Resources and Hydraulic Engineering } \\
\text { Soulsby, Chris; University of Aberdeen, School of Geosciences } \\
\text { Cheng, Qin-Bo; Hohai University, College of Hydrology and Water } \\
\text { Resources } \\
\text { Binley, Andrew; Lancaster University, Lancaster Environment Centre } \\
\text { Jiang, Rui; Hohai University, State Key Laboratory of Hydrology-Water } \\
\text { Resources and Hydraulic Engineering } \\
\text { Tao, Min; Hohai University, State Key Laboratory of Hydrology-Water } \\
\text { Resources and Hydraulic Engineering }\end{array}$ \\
\hline Keywords: & $\begin{array}{l}\text { Cockpit karst, critical zone, hydrological functions, geophysical survey, } \\
\text { tracers }\end{array}$ \\
\hline & \\
\hline
\end{tabular}


1 Characterizing the heterogeneity of karst critical zone and its hydrological function: an

2 integrated approach

3

4 Xi Chen ${ }^{1,2 *}$, Zhicai Zhang ${ }^{2,3}$, Chris Soulsby ${ }^{3}$, Qinbo Cheng ${ }^{2,4}$, Andrew Binley ${ }^{4}$, Rui Jiang ${ }^{2}$, $5 \mathrm{Min} \mathrm{Tao}^{2}$

6

7 1: Institute of Surface-Earth System Science, Tianjin University, Tianjin China

8 2: State Key Laboratory of Hydrology-Water Resources and Hydraulic Engineering, Hohai

9 University, Nanjing 210098, China

10 3: School of Geosciences, University of Aberdeen, Aberdeen AB24 3UF, United Kingdom

11 4: Lancaster Environment Centre, Lancaster University, Lancaster, LA1 4YQ, United 12 Kingdom

13

14 15

16 Submitted to Special issue: Water in the Critical Zone 17 


\section{Abstract}

20 Spatial heterogeneity in the subsurface of karst environments is high, as evidenced by the

21 multi-phase porosity of carbonate rocks and complex landform features that result in marked

22 variability of hydrological processes in space and time. This includes complex exchange of

23 various flows (e.g. fast conduit flows and slow fracture flows) in different locations. Here, we

24 integrate various "state-of-the-art" methods to understand the structure and function of this

25 poorly-constrained critical zone environment. Geophysical, hydrometric and tracer tools are

26 used to characterize the hydrological functions of the cockpit karst critical zone in the small

27 catchment of Chenqi, Guizhou province, China. Geophysical surveys, using electrical

28 resistivity tomography (ERT), inferred the spatial heterogeneity of permeability in the

29 epikarst and underlying aquifer. Water tables in depression wells in valley bottom areas, as

30 well as discharge from springs on steeper hillslopes and at the catchment outlet, showed

31 different hydrodynamic responses to storm event rainwater recharge and hillslope flows.

32 Tracer studies using water temperatures and stable water isotopes ( $\delta \mathrm{D}$ and $\delta^{18} \mathrm{O}$ ) could be

33 used alongside insights into aquifer permeability from ERT surveys to explain site- and

34 depth-dependent variability in the groundwater response in terms of the degree to which "new"

35 water from storm rainfall recharges and mixes with "old" pre-event water in karst aquifers.

36 This integrated approach reveals spatial structure in the karst critical zone and provides a

37 conceptual framework of hydrological functions across spatial and temporal scales.

38 Key words: Cockpit karst; critical zone; hydrological functions; geophysical survey; tracers;

39 stable isotopes. 
40

41

42

43

$44 \sim 540 \times 10^{3} \mathrm{~km}^{2}$ over eight provinces. The karst terrain displays a geomorphic transition as the

45 topography gradually descends by 2,000 metres over 700 kilometres from the western

46 Yunnan-Guizhou Plateau to the eastern Guangxi Basin. Cockpit karst is a specific

47 geomorphology found in some tropical areas underlain by limestone formations. Conical hills

48 and star shaped valleys are characteristic of such karst landscapes. Due to the distinct nature

49 of karst geology and geomorphology in the humid tropics and subtropics, spatial

50 heterogeneity in the subsurface is high, evidenced by specific landforms features (e.g. heavily

51 fractured outcrops, sinkholes etc.) and complex subterranean conduit networks. This leads to

52 highly dynamic variability of hydrological processes in space and time. This heterogeneity in

53 karstic environments and their rapidly evolving nature makes them extremely vulnerable to

54 natural and anthropogenic hazards. Hillslope springs and groundwater in valley bottom

55 depressions in cockpit karst areas are the main water resources for local agriculture, industry

56 and domestic use. However, the high hydrological variability results in vulnerability to the

57 frequent occurrences of floods and droughts. Consequently, understanding the karst critical

58 zone, its structures and hydrological functions in the southwest karst region of China is

59 essential to mitigate natural disasters and adapt appropriate management strategies for

60 sustainable water resource utilization. 
61 Hydrological responses to rainfall in cockpit karst areas can be conceptualised as in Fig 1.

62 The hydrological processes include rainfall infiltration in the soil and epikarst, water storage

63 and flow in the transmissive zone, and hydrological connectivity between hillslope and

64 depression units. To consider the effects of marked heterogeneity in the profile of the karst

65 critical zone on hydrological function, the profile can be sub-divided into soil, epikarst,

66 unsaturated and phreatic zones (Perrin et al., 2003). On the hillslope, since the permeability

67 usually reduces with the depth (Williams, 1983) or less permeability layers underlie the

68 epikarst zone, infiltrated water usually flows out as a spring. The phreatic zone is regarded as

69 a transmissive zone through its well-developed conduit network (e.g. Emblanch et al., 2003;

70 Perrin et al., 2003). Nevertheless, it is extremely heterogeneous in space. For example, the

71 solutional conduits in karst aquifers connect with intergranular pores and fractures (often

72 termed as matrix porosity), showing dual or even triple porosity zones (Worthington et al.,

73 2017). Thus, karst aquifers are often conceptualized as dual porosity systems as residence

74 times in the matrix are several orders of magnitude longer than those in the conduits

75 (Goldscheider and Drew, 2007). However, even for the matrix porosity at a specific site,

76 fracture apertures can widely vary, e.g. 0.01-0.1 mm (Long et al. 1982; Hyman et al. 2015);

77 and for larger conduits, the density and connectivity with the surrounding fractures can vary

78 greatly due to heterogeneity in the stratigraphy and geologic structure. Consequently, the

79 characterization of the functioning of such complex systems remains a great challenge.

80 Hydrometric observations and tracer investigations are traditional and effective

81 approaches to inferring flow processes within karst systems (Fig 1). Water table response is 
particularly sensitive to changes in hydrometeorological forcing because of the direct

83 connectivity of the water table with the ground surface in surficial and shallow aquifers

84 (Winter, 1999; Healy and Cook, 2002; Sophocleous, 2002; Lee et al., 2006). The water-table

85 rise and fall during a specific storm period can be translated into a corresponding amount of

86 groundwater recharge and discharge (Sophocleous, 1991; Xie and Yuan, 2010; Fan et al, 2014;

87 Biswas et al, 2017). In karst areas, abundant springs on hillslopes and at catchment outlets

88 reflect regional flow accumulation along conduits and underground channels. Spring

89 hydrographs can be used to characterize karst systems (Kovacs and Perrochet, 2008) and

90 better understand system behavior during floods (Winston and Criss, 2004) or droughts

91 (Fiorillo, 2009).

92 As water flowing through soils or fractures carries sensible heat that can affect

93 subsurface water temperatures on mixing (Anderson, 2005; Rau et al., 2014), distributed

94 temperature measurements can provide excellent indications of flow and connectivity. Using

95 water temperature as a tracer can thus help assess groundwater flow, groundwater-surface

96 water exchanges (Becker et al., 2004; Niswonger et al., 2005; Lowry et al., 2007; Irvine et al,

97 2015), flow paths, mixing effects and residence times (Sun et al., 2016). This is especially

98 useful in karst aquifers as fast flows overcome limitation of heat tracing at lower velocities

99 (Rau et al., 2010, Rau et al., 2014). As rainwater may has different temperatures to

100 groundwater, the arrival of new recharge at a karst spring is evidenced by changing water

101 temperature (Ford and Williams, 2013). Subsurface temperature variability can thus be used 
102 to assess the degree of connectivity and relative importance of mixing (Hartmann et al., 2014;

103 Mudarra et al., 2014).

104 Isotope studies have also substantially increased our understanding of detailed

105 hydrological flow paths and mixing processes in the critical zone (Sprenger et al., 2017, 2018).

106 Stable isotopes of water $\left(\delta^{18} \mathrm{O}\right.$ and $\left.\delta^{2} \mathrm{H}\right)$ have also been widely used to provide insight into the

107 functioning of karst systems (Barberá and Andreo, 2012; Mudarra and Andreo, 2011), the

108 mixing of water from different sources (Aquilina et al., 2006; Plummer et al., 1998), and the

109 their residence times (Batiot et al., 2003; Long and Putnam, 2004). Due to the high degree of

110 variability of karst systems, continuous monitoring or event-based high-frequency sampling is

111 essential, but logistically challenging (Goldscheider and Drew, 2007).

112 Hydrometric monitoring and tracer studies provide direct observations of

113 hydro-dynamics which can indirectly hypothesize karst critical zone structures. However,

114 explaining hydrological variability and identifying controls rely on detail information on karst

115 hydrogeological properties in space. For example, Lee and Krothe (2001) used dissolved

116 inorganic carbon (DIC) and $\delta^{13} \mathrm{DIC}$ as tracers for conceptualizing hydrological functions

117 using a four-component mixing model (rain, soil water, epikarstic water and diffuse phreatic

118 water) for a karstic flow system. Similarly, Jiang et al. (2008) inferred runoff response

119 thresholds in the epikarst by monitoring the spring's discharge, $\mathrm{pH}$, electrical conductivity,

120 temperature and rainfall. Increasingly, however, geophysical techniques are being used to

121 provide more direct evidence about the geological setting of a karst system. Survey

122 techniques, such as ground penetrating radar (GRP) and electrical resistivity tomography 
123 (ERT), provide an efficient means of describing the karst structure, mapping karst conduits

124 (Carrière et al., 2013; Martínez-Moreno et al., 2014) and defining the soil-rock interface

125 (Chalikakis et al., 2011). Such geological evidence is crucial for delineating hydraulic

126 structures, such as complex subsurface drainage networks in the karst which can link local

127 fissure and fracture networks with the dominant large conduit systems (Chalikakis et al, 2011;

128 Hartmann et al., 2014; Binley et al., 2015). These insights can be particularly powerful if

129 geophysical approaches are integrated with hydrometric and tracer observations and at the

130 same study site (e.g. Soulsby et al., 2016).

131 Different methodologies have advantages and limitations (see Goldscheider and Drew,

132 2007) so isolated measurements and observations are inadequate for characterizing a karst

133 system. Although many researchers apply combinations of such methods for assessing the

134 hydrology karst areas, they seldom integrate insights from multi-scale distributed geophysical

135 surveys, hydrometric observations and tracer investigations. Consequently, in the southwest

136 karst region of China, we lack a conceptual framework that characterizes spatial heterogeneity

137 hydrological functioning at multiple scales and/or in different geographic regions.

138 The overall aim of this study was to integrate these approaches to visualize the complex

139 heterogeneity in karst critical zone and its effect on hydrological functions. By so doing, the

140 study will also help identify dominant processes to incorporate in the structure of hydrological

141 models. We based the investigation in the long-term study site of Chenqi in the cockpit karst

142 region of Guizhou province, southwest China. Our objectives were to: (1) undertake

143 geophysical surveys using electrical resistivity tomography to characterize the structure of the 
144 karst critical zone and identify variations in the permeability which define fast and slow flow

145 domains in karst aquifers. (2) Monitor groundwater levels in wells and discharge from 146 hillslope springs and the catchment outlet to characterize the spatial and temporal variations

147 of hydrodynamic response to rainfall events. (3) Use stable isotopes of water $\left(\delta^{18} \mathrm{O}\right.$ and $\left.\delta^{2} \mathrm{H}\right)$

148 qualitatively understand how "new" event water from rainwater and "old" pre-event water

149 from low permeability aquifers recharges mix and contribute to catchment discharge,

150 particularly during heavy rainfall in the vertical profiles. Improved conceptualization of a dual

151 flow system that accounts for local aquifer heterogeneity influences on the hydrological

152 connection between fast and slow reservoirs is proposed.

1542 Study area, data and methods

$155 \quad 2.1$ Study catchment

156 The study was focused in the small $\left(1.2 \mathrm{~km}^{2}\right)$ Chenqi catchment, located in the Puding

157 Karst Ecohydrological Observation Station, Guizhou Province, southwest China (Fig. 2). It is

158 a typical cockpit karst landscape, with surrounding conical hills separated by star shaped

159 valleys. Surface elevation ranges from $1320 \mathrm{~m}$ at the catchment outlet to a maximum of 1500

$160 \mathrm{~m}$. Geological strata in the basin include dolostone, thick and thin limestone, marlite and

161 Quaternary soil (profiles of A-A' and B-B' in Fig 2). Limestone formations form the higher

162 elevation areas with 150-200 m thickness, which lie above an impervious marlite formation.

163 The Quaternary soils are irregularly developed on carbonate rocks and unevenly distributed,

164 with outcrops of carbonate rocks covering $10-30 \%$ of the catchment. Dominant vegetation 
165 ranges from deciduous broad-leaved forest on the upper and middle parts of the steep

166 hillslopes and corn and rice paddy at the low of the gentle hillslopes and depression.

167 The catchment is located in a region with a subtropical wet monsoon climate with mean

168 annual temperature of $20.1^{\circ} \mathrm{C}$, highest in July and lowest in January. Annual mean

169 precipitation is $1140 \mathrm{~mm}$, almost all falling in a distinct wet season from May to September

170 and a dry season from October to April next year. Average monthly humidity is high, ranging

171 from $74 \%$ to $78 \%$.

\section{$172 \quad 2.2$ ERT survey in the valley depression}

173 Electrical resistivity tomography (ERT) was used to survey the geological properties

174 along five transects crossing the depression (Fig 3). The surveyed profiles were located

175 adjacent to four observation wells (see below) and three sinkholes to identify the geological

176 controls on groundwater dynamics. The surveys were carried out in spring 2017 using a

177 Syscal Pro (Iris Instruments, France) resistivity meter with electrode spacing between 2 and

$1785 \mathrm{~m}$. We used a dipole-dipole electrode configuration (see for example, Binley, 2015) with

179 dipole spacings of one, two and three times the electrode separation and up to 20 levels. The

180 dipole-dipole configuration was selected to allow sensitivity of lateral variation in resistivity.

181 Inversion of the ERT data was carried out using the code R2

182 (http://www.es.lancs.ac.uk/people/amb/Freeware/R2/R2.htm). The resulting composite ERT

183 image is shown in Fig 3. The resistivity ranges from $\sim 15 \Omega \mathrm{m}$ to $\sim 8000 \Omega \mathrm{m}$. Based on ERT

184 surveys carried out adjacent to outcrops in neighbouring areas of the catchment we interpret

185 the ERT results in Fig 3 as: (i) an upper layer consisting of moist soils or extensively 
186 fractured rock (resistivity $<100 \Omega \mathrm{m}$, blue in Fig. 3); (ii) carbonate rock with a high secondary

187 porosity (and hence permeability) $(100 \Omega \mathrm{m}<$ resistivity $<1000 \Omega \mathrm{m}$, green/yellow in Fig. 3);

188 (iii) an underlying carbonate rock with low secondary porosity and hence relatively low 189 permeability (resistivity $>1000 \Omega$ m, red in Fig. 3).

190 The ERT image shows that the depression aquifer is highly heterogeneous in both the

191 horizontal direction and vertical direction. Based on our interpretation of the ERT image: well

192 W1 is surrounded by the less permeable aquifer (red colour) and its upper layer of carbonate 193 rock appears particularly impermeable; wells W3 and W4 are located in the higher 194 permeability area (blue colour); well W5 is located in the less permeable aquifer and its top 195 soils (blue colour) and the carbonate rock in the upper layer (yellow colour) is relatively more 196 permeable than that in the deep layer (red colour). The relatively permeable upper layer at W5 197 appears much thinner than those at other wells.

198 In a previous study, a GPR MALA Professional Explorer (ProEx) System was used for 199 investigation of the fracture zone thickness on the hillslope. The epikarst thickness on the 200 hillslope was identified to be in a range of 7.6 12.56 m. Along the hillslope, the thickness and 201 the epikarst zone at the lower areas is deeper than in the upper areas (Zhang et al. 2013).

\section{$202 \quad 2.3$ Hydrometric observations}

203 In the Chenqi catchment, groundwater levels in the valley depression were routinely 204 monitored at the four wells (W1, W3, W4 and W5) with depth to ground surface of 35, 23, 13 205 and $16 \mathrm{~m}$, respectively. The well screening was installed over the whole depth for each of the 206 wells to reflect local flow exchanges at various depths. Flows discharging from a hillslope 
207 spring (HS) at the foot of the eastern steep hillslope and leaving the catchment outlet were 208 measured by v-notch weirs (Fig. 2). The water level and temperature at each well, the 209 hillslope spring and the catchment were automatically recorded by HOBO U20 water level 210 logger (Onset Corporation, USA) with a time interval of 15 minutes. Additionally, an 211 automatic weather station was set on the upper hillslope to record precipitation, air 212 temperature, and air humidity and pressure.

213 Data collection ran from 28 July 2016 to 30 October 2017. Hourly variations of rainfall, 214 discharge from the hillslope spring and catchment outlet, as well as water levels in the four 215 wells are shown in Fig 4, and their corresponding temperature are shown in Fig 5. Statistical 216 characteristics of water levels, flow discharges and temperatures are summarized in Table 1 217 and Table 2.

\section{$218 \quad 2.4$ Stable isotope analysis}

219 For isotope analysis, the hillslope spring (HS), groundwater from outlet and rainfall were 220 sampled at daily intervals during the wet season from June to August 2017. Additionally, they 221 were intensively sampled during eight rainfall events in the wet season using an autosampler 222 set to hourly intervals. Depression groundwater was sampled from the four wells during four 223 rainfall events within the study period; in each event, water samples were collected before, 224 during and after rainfall. At each well, water was sampled from multiple depths with a 225 depth-specific sampler to give a profile of the isotopic composition of the groundwater 226 column. All water samples (1695 replicates) were collected by $5 \mathrm{ml}$ glass vials. The stable 227 isotopic composition of $\delta^{2} \mathrm{H}(\delta \mathrm{D})$ and $\delta^{18} \mathrm{O}$ ratios were determined using the MAT 253 laser 
228 isotope analyser (the instrument precision $\pm 0.5 \%$ for $\delta^{2} \mathrm{H}$ and $\pm 0.1 \%$ o for $\delta^{18} \mathrm{O}$ ). Isotope ratios

229 are reported in the d-notation using the Vienna Standard Mean Ocean Water standards

230 (Coplen, 1994). The analyzed results of the isotopic values are shown in Figs 6-8.

231

2323 Results

$233 \quad 3.1$ Hydroclimatic and groundwater variability in the depression

234 Generally, the hydrometric observations reveal sharp rises and falls in water level at the

235 four wells in response to rainfall events (Fig. 4). However, the magnitude of the water table

236 response and the rate of the water table recessions exhibit differences at the four wells, which

237 indicates spatial differences in the groundwater response to recharge and attenuation of the

238 hydrograph. The magnitude of the temporal dynamic is larger and more attenuated at W3 and

239 W4 in the low electrical resistivity (interpreted higher permeability) areas, and abrupt at W1

240 and W5 where particularly heavy rainfall is needed to produce a large water table rise. These

241 differences are apparent in the coefficient of variation (CV) of water level data for W3 and

242 W4 (0.21 and 0.61, respectively), whilst the CV of W1 and W5 is only 0.03 and 0.07 ,

243 respectively (see Table 1).

244 Temporal variability in temperature clearly demonstrates that groundwater dynamics at

245 W3 and W4 are more directly influenced by hydroclimate variability compared with W1 and

246 W5 (Fig 5). The former wells show marked temperature excursions towards air temperatures

247 in response to rainfall events, whilst the latter wells exhibit highly attenuated temperatures

248 typical of deeper groundwater. As shown in Table 2, the CV of water temperature at W3 and 
249 W4 is 0.026 and 0.036 , while the CV of W1 and W5 is only 0.004 and 0.012 , respectively.

250 The sharp rise and drop of water temperature at W3 and W4 during rainfall is clearly

251 consistent with the fast arrival of freshly infiltrated rainwater. In contrast, the limited seasonal

252 fluctuation of water temperatures at W1 and W5 indicate little evidence of rainfall recharge

253 consistent with the interpreted low permeability in the upper layers (high resistivity zone in 254 Fig 3).

255 As shown in Fig. 6 and Table 3, temporal variations of rainfall $\delta \mathrm{D}$ and $\delta^{18} \mathrm{O}$ at Chenqi 256 are marked, ranging from -120.2 to $-17.9 \%$ for $\delta \mathrm{D}$ and from -16.4 to $0 \%$ for $\delta^{18} \mathrm{O}$. The $\delta \mathrm{D}$ 257 and $\delta^{18} \mathrm{O}$ responses amongst the depression wells are attenuated or damped but they are 258 markedly different in this restricted area due to spatial heterogeneity of the karst aquifer 259 (Table 3 and Fig 6). In terms of the temporal changes in $\delta \mathrm{D}$ and $\delta^{18} \mathrm{O}$, values tended to 260 become more negative in response to direct effects of rainwater recharge into the aquifer 261 during storm events. Compared with isotope values at W1 and W5, groundwater at W3 and 262 W4 is clearly receiving rainfall that has marked changes in isotope values evident in the 263 variability in Fig 6 and the large range in Table 3. Groundwater at W5 is the most stable (Fig 264 6) and has the lowest range in Table 3 implying a limited influence of new recharge from 265 rainfall. However, W1 is close to the catchment outlet and the high permeability of its lower 266 aquifer inferred from the ERT survey may allow exchange with the subsurface flow leaving 267 the catchment (Fig 3). The isotopic signatures of groundwater at W1 show intermediate 268 isotopic values compared to the upper catchment (lower than the most stable water at W5 and 
269 higher than those at W3 and W4 where the direct rainfall influence is evident), suggesting that

270 groundwater at W1 likely reflects mixing of flow paths from the upper depression.

271 However, at the different stages of the storm event response (e.g. the sharp rises and falls

272 in water level before and after rainfall), the degree of "new" event water recharge from

273 rainfall and "old" water release from previous storage amongst the four wells differed

274 according to the $\delta \mathrm{D}$ values from the depression aquifer (Fig 7). Generally, recharge of new

275 rainfall occurs in the early recession phase of the groundwater response, and the release of

276 previously stored (old) water occurs later in the recession. The impact of infiltrating new

277 water in the early recession can be distinguished from changes of the $\delta \mathrm{D}$ values before rainfall

278 and in the early recession in Fig 7; for rainfall events No. 1 and 4, as the rainwater $\delta \mathrm{D}$ values

279 are much more negative than those of the groundwater. The subsequent decline of the $\delta \mathrm{D}$

280 values in these depression wells indicates the ingress of isotopically depleted (newer)

281 rainwater. However, for rainfall event No 3, as the rainwater $\delta \mathrm{D}$ is more enriched than

282 groundwater, the rise of the $\delta \mathrm{D}$ values at these depression wells also indicates the impact of

283 more enriched rainwater recharge.

284 In the later recession, the effects of recent recharge generally decline. Hence, the $\delta \mathrm{D}$

285 values of groundwater increase again for rainfall events No 2 and 4. This would be consistent

286 with the release of older water into aquifer. As shown in Fig 7, changes of the $\delta \mathrm{D}$ values in

287 the three events are evident for wells W3, W4 and W5, but the changes become less

288 distinguishable for well W1 close to the catchment outlet (Fig 7). This also indicate that 
groundwater at the catchment outlet can be attributed by regional flow that endures a relatively high mixture of event new water with storage old water.

\subsection{Hillslope-depression flow connectivity}

Hillslope-depression flow connectivity can be identified from temporal variability in

293

294

295

296

297

298

299

300

301

302

303

304

305

306

307

308

309

water table levels, temperatures and isotopic tracers at W4 located at the base of a steep

hillslope and the hillslope spring (HS). Despite the marked response to rainfall events, the water level at W4 recesses much more slowly after rainfall ceases compared to the other wells

(Fig 4). The slow recession in this interpreted high permeability area possibly arises from some additional water from upslope areas that continues to recharge the depression aquifer after rainfall ceases.

Water temperatures and isotopic values at W4 and the hillslope spring (HS) further provided evidence for hillslope contributions to the depression. Water temperatures at both sites show a similar pattern of the seasonal variations with air temperature and fluctuations with rainfall (see Fig 5), i.e. higher in the summer season and lower in the winter season. Water isotopic values at W4 are closest to these at the hillslope spring (HS), particularly, during the rainfall period (see the yellow for W4 and the green for HS in Fig 6 and mean values in Table 3). Additionally, in the winter season, water temperature at W4 is more attenuated and lags behind that of the hillslope spring, which indicate that the hillslope flow is faster than the depression groundwater flow at W4. In the summer season, the response of water temperature to rainfall at W4 is more marked that those of the hillslope spring, which indicate that the depression groundwater flow at W4 could receive hillslope flow as well as rainfall recharge. 


\subsection{Effect of vertical heterogeneity on hydrological functions}

311 The ERT survey demonstrates strong vertical heterogeneity of the karst aquifer at each

312 site (Fig 3). The $\delta \mathrm{D}$ values at various depths to groundwater table (the uncertainty bar in Fig 7)

313 illustrates the effect of vertical heterogeneity on hydrological functions. For the four wells,

314 the range of the vertical variation in $\delta \mathrm{D}$ is generally much higher for $\mathrm{W} 1$ and $\mathrm{W} 3$ in the

315 central and outlet depression, than the wells of W4 and W5 at the upper depression. This is

316 consistent with groundwater in the upper depression areas mixing more effectively in a

317 vertical direction than groundwater in the center and catchment outlet.

318 The isotopic values prior to rainfall and at the early and late stages of the recession for

319 rainfall event 4 (12 to 14 August 2017) in Fig 8 further demonstrate the control of vertical

320 heterogeneity in aquifer structure on hydrological function. The event has a total rainfall of

$32136.8 \mathrm{~mm}$ and the rainfall $\delta \mathrm{D}$ value ranging between -109.8 and $-74.8 \%$ with a mean of

$322-90.7 \%$, with the most negative values coinciding with peak rainfall. The event-scale changes

323 in the vertical distribution of the $\delta \mathrm{D}$ values are different for the four wells.

324 (1) W1: there is little vertical variation of the $\delta \mathrm{D}$ values before rainfall (Fig $8 \mathrm{a}(\mathrm{i})$, which

325 indicates strong pre-event vertical mixing. Early in the recession when groundwater levels

326 rapidly decline, the mean $\delta \mathrm{D}$ value declined from -60.5 to $-61.6 \%$ (Fig $8 \mathrm{a}(\mathrm{i})$ ), indicating some

327 new water influence. Moreover, the flow paths of the new water ingress can be identified

328 from the vertical variation of the $\delta \mathrm{D}$ values (see $13 / 8$ line in Fig $8 \mathrm{a}(\mathrm{ii})$ ), i.e. at the depths of

$3297-8 \mathrm{~m}$ and below $18 \mathrm{~m}$ where the $\delta \mathrm{D}$ values rapidly decline. These depths correspond to low

330 resistivity regions indicative of high permeable layers (green in Fig 8a(iii)). Since the 
temperature variation in Fig 5 and ERT image in Fig 8a(iii) suggest that the lower layer at W1

332 receives little rainfall recharge, the decline of the $\delta \mathrm{D}$ values seems most likely explained by 333 exchange of groundwater in the high permeability depths with the regional flow (affected by new rainfall). Between the two higher permeability layers, water in the less permeability layer

335 (yellow in Fig 8a(iii)) changes only little, indicating that flow exchange between the 336 permeable and less permeable layers is weak.

337 Later in the recession, the $\delta \mathrm{D}$ value increases to $-60.8 \%$, which is close to the 338 pre-rainfall value. At this time, vertical variations on 14 August (Fig 8a(ii)) demonstrate that 339 the $\delta \mathrm{D}$ value in the lower permeable layer (below $18 \mathrm{~m}$ ) recovers close to pre-event conditions.

340 Surprisingly, the $\delta \mathrm{D}$ values in the upper less permeable layer (the depth of $7.5 \mathrm{~m}$ ) become

341 much less negative. This suggests that there may be release or displacement of older water,

342 possibly attributable to antecedent storage from the upper less permeable layer (Fig 8a(iii)).

343 (2) W3: temporal variation of $\delta \mathrm{D}$ values over the three periods (Fig.8b(i)) is similar but

344 more marked than that at W1. Vertical variation at W3 (Fig 8b(ii)) is very different over the

345 three periods. Before the rainfall on 12 August, the $\delta \mathrm{D}$ values generally are less negative

346 throughout the water column. The more negative values in the upper profile may reflect more

347 recent depleted rainfall and increasingly older water with depth. This seems consistent with

348 the decreasing permeability with depth at W3 implied by the less resistive upper profile and 349 more resistive deeper layers (Fig 8b(iii)).

350 In the early recession on 13 August, $\delta \mathrm{D}$ values (Fig 8b(ii)) become more negative and 351 almost uniform in vertical distribution. This implies that new water from recharge of 
352 rainwater rapidly mixes with older pre-event water in storage. In the later recession,

353 groundwater isotope values recover indicating lessening influence of new water, though

354 values do not recover to pre-rainfall levels. Meanwhile, groundwater in the upper aquifer (e.g.

355 above $8 \mathrm{~m}$ ) still remains negative with continued new water influence. This suggests that the

356 upper, more permeable (i.e. with lower resistivity) aquifer stores more new water during

357 rainfall and releases this thereafter.

358 (3) W4: as shown in Fig.8c(i), the water level recession is slower than the other wells but

359 the mean of the $\delta \mathrm{D}$ value declines greatly from $-59 \%$ before rainfall to $-67 \%$ in the early

360 recession and then recovers to $-65.9 \%$ in the later recession. The marked decline of $\delta \mathrm{D}$ is

361 again consistent with substantial influence of event water ingress. Prior to rainfall when

362 groundwater level is low ( $>4 \mathrm{~m}$ in depth), the vertical distribution of the $\delta \mathrm{D}$ is nearly uniform

363 (Fig 8c(ii)). In the early recession when water levels remain high, groundwater in the upper

364 aquifer (above the depth of 3.5) tends to be more negative indicating event new water 365 influence.

366 In the later recession, the $\delta \mathrm{D}$ values below $3.5 \mathrm{~m}$ become a little more negative, whilst the

367 upper aquifer remains the same. As W4 is located at the foot of a steep hillslope, it is likely

368 that lateral flow from the hillslope contributes recharge since the ERT image suggests that this

369 is a high permeability area strongly connected to the hillslope flow path (Fig 3 and Fig $3708 \mathrm{c}(\mathrm{iii}))$.

371 (4) W5: The water level and isotopic response at W5 contrasts markedly to the other

372 wells, i.e. a transient fluctuation of water level and abrupt change in $\delta \mathrm{D}$ (Fig $8 \mathrm{~d}(\mathrm{i})$ ). The 
373 unresponsive groundwater likely reflects that the well is located in an impervious (high

374 resistivity) area (Fig 8d(iii)). After the water level decline, groundwater has a limited decrease

375 in $\delta \mathrm{D}$ (from -58 to $-58.4 \%$ ) in the early post-event period, and continuous decrease (to

$376-59.6 \%$ ) later. The continuous decease of $\delta \mathrm{D}$ values indicates a longer memory of the much

377 less permeability aquifer to the limited recharge.

378 Before rainfall, the vertical values of $\delta \mathrm{D}$ are highly varied; water in the upper layer has

379 less negative values of $\delta \mathrm{D}$, whilst waters at depths of $7.4 \mathrm{~m}$ and below $8 \mathrm{~m}$ have more negative

380 values of $\delta \mathrm{D}$ (Fig 8d(ii)). The much older water in the upper layer suggests strong evaporative

381 effect in the non-rainfall period since the top soils and the upper permeability rock layer are

382 thin (Fig 8d(iii)) and thus evaporative effect is strong. Marked changes of the $\delta \mathrm{D}$ values in the

383 lower depths (e.g. below 7.4m) reflects that there are still some permeable fractures, in which

384 new water could be arrival. After the end of the brief water table response, the vertical $\delta \mathrm{D}$

385 values (13 August in Fig 8d(ii)) in the lower layer (e.g. below 7.4m) are more negative than

386 the upper layer. This would imply that after a short response to rainfall (Fig 8d(i)), event "new"

387 water in the upper layer rapidly mixes with the surrounding "old" water, but "new water" still

388 ingresses into the lower depths. In the later post-event period, the relatively uniform vertical

389 values of $\delta \mathrm{D}$ (14 August in Fig 8d(ii)) show recharged event water mixing in the whole

390 profile.

391 Discussion and conclusions

$392 \quad 4.1$ Discussion

393 4.1.1 Conceptualizing hydrological functions in cockpit karst catchment 
394 Variation in hydrological functions (rainfall recharge, horizontal and vertical flow

395 exchange at sites and hillslope-depression connectivity) in the heterogenous subsurface of our

396 cockpit karst catchment can be summarized as in Fig 9. Fast and frequent rainwater recharge

$397 I_{f}$ into the epikarst zone on the hillslope (HS) and permeable depression (e.g. W3 and W4)

398 leads to local flow being "active" and young, whilst infrequent rainwater recharge into the

399 less permeable depression (e.g. W1 and W5) leads to local flow being less active or inactive

400 and "old". For the hillslope-depression-outlet connectivity, the mean isotopic value at outlet

$401(\delta \mathrm{D})$ is between relatively "new" water from fast flows in HS and high permeability

402 depression areas (W3 and W4) $\left(\delta \mathrm{D}_{f}\right)$ and "old" water from slow flows in low permeability

403 depression areas (W1 and W5) $\left(\delta \mathrm{D}_{\mathrm{s}}\right)$. Thus, outlet water (Q and $\left.\delta \mathrm{D}\right)$ can be viewed as a

404 mixture of hillslope $\left(Q_{f}\right.$ and $\left.\delta \mathrm{D}_{f}\right)$ and depression flow $\left(Q_{s}\right.$ and $\left.\delta \mathrm{D}_{\mathrm{s}}\right)$ at various sites.

405 Fig 8 shows that temporal change in hydrological functions is closely linked to vertical

406 heterogeneity with different composition of the active, less active and inactive areas. The

407 structure of the vertical profile can be generalized as Fig 9 and classified into two types: (a)

408 profiles consisting of two different permeability layers, e.g. a high permeability layer

409 confined by a lower permeability layer at W1 and a high permeability layer with limited

410 thickness perched on a less permeability layer at W5. (b) profiles comprising one layer but

411 their permeability decreasing with depth, e.g. at W3 and W4. Here, the profile flow function

412 can be still illustrated by exchange of fast and slow flow reservoirs (Fig 9) but the relative

413 contribution of fast and slow flow reservoirs is a function of depth $h$, i.e. $Q \delta \mathrm{D}(\mathrm{h})=Q_{f} \delta \mathrm{D}_{f}$

$414(\mathrm{~h})+Q_{s} \delta \mathrm{D}_{\mathrm{s}}(\mathrm{h})$, in where flows and isotopic values in each reservoir are influenced by rainfall 
415 recharge $I_{f}$ and water exchange between fast and slow reservoirs $Q_{E}=K_{E}(\mathrm{~h})\left(W T_{f}-W T_{s}\right)\left(W T_{f}\right.$

416 and $W T_{s}$ represent water table in the fast and slow reservoirs, respectively, and $K_{E}$ is exchange

417 coefficient).

10

418 Such depth variability of hydrological function can be used to explain the hydrological

419 response of the observation wells (Fig 9). The profile depth $h$ at W1 and W5 can be divided

420 into two homogenous layers $(h 1$ and $h 2)$. At W1, we can hypothesize that recharge of the fast

421 flow reservoir $\left(I_{f}\right)$ is negligible due to the upper confining layer. The fast flow $Q_{f}$ can be

422 highly connected with the regional flow but has limited exchange with the slow flow reservoir

$423 Q_{s}$ i.e. $Q_{E}$ is small, evidenced by little change of the $\delta \mathrm{D}$ value in the less permeable layer for

424 W1 in Fig 8a(i). At W5, groundwater in the profile id dominated by the slow reservoir $Q_{s}$ in

425 the lower layer $(\mathrm{h} 2>>\mathrm{h} 1)$. Before rainfall, when the water level $\mathrm{WT}_{\mathrm{s}}$ is low, limited perched

426 water $Q_{f}$ in the upper layer ingresses into the slow reservoir ( $Q_{E}$ can be neglected). During

427 rainfall when the upper water table $W T_{f}$ rises higher than the low water table $W T_{s}$, pressure

428 drives new event water $Q_{f}$ into the slow reservoir in a short time ( $Q_{E}$ is slight and transient).

429 After rainfall when a short pulse of water table variation ends $\left(W T_{f}<=W T_{s}\right)$, the pressured

430 new water in the slow reservoir $Q_{s}$ is slowly released.

431 The hydrological functions in the profiles W3 and W4 can be still conceptualized into

432 the fast and slow flow reservoirs in which fast flow contribution $\left(Q_{f}\right)$ to the whole profile flow

433 gradually reduces with depth whilst the slow flow contribution $\left(Q_{s}\right)$ increases. As the profile

434 is highly permeable and unconfined, direct recharge into the fast reservoir $\left(I_{f}\right)$ and new event

435 water quickly mixes with pre-event water in the vertical direction under $W T_{f}>=W T_{s}$ during

21

http://mc.manuscriptcentral.com/hyp 
436 rainfall (large $Q_{E}$ ). In the later recession when water table is low and $W T_{f}<=W T_{s}$, the older

437 water in the slow flow reservoir is mostly released from the lower layers (Fig.9b), i.e. less

438 negative $\delta \mathrm{D}_{\mathrm{s}}(\mathrm{h})$ and larger $Q_{s}$ in $Q \delta \mathrm{D}(\mathrm{h})=Q_{f} \delta \mathrm{D}_{f}(\mathrm{~h})+Q_{s} \delta \mathrm{D}_{\mathrm{s}}(\mathrm{h})$. The unconfined aquifer at W4

439 is similar to W3 but the aquifer at W4 receives direct recharge $\left(I_{f}\right)$ and inputs from hillslope

440 flow $\left(Q_{h}\right)$ during events when water levels are high, then quickly infiltrates into the low slow

441 reservoir (large $Q_{E}$ ). After rainfall, the upper fast reservoir retains a water level higher than

442 the slow reservoir $\left(W T_{f}>=W T_{s}\right)$ since the hillslope flow $\left(Q_{h}\right)$ continually inputs into the 443 aquifer (evidenced by more negative of the $\delta \mathrm{D}$ values in Fig 7c(ii)).

444 In any specific landscape unit (e.g. depression), outlet flow $Q$ comes from fast and slow

445 flow composition at various sites, i.e. $Q=\sum_{1}^{n} Q_{f}+\sum_{1}^{n} Q_{s}$, and $Q \delta \mathrm{D}=\sum_{1}^{n} Q_{f} \delta \mathrm{D}_{f}+\sum_{1}^{n} Q_{s} \delta \mathrm{D}_{\mathrm{s}}$,

446 where $n$ is the total number of the sites. Meanwhile, in each reservoir, the discharge $\left(\sum_{1}^{n} Q_{f}\right.$

447 or $\left.\sum_{1}^{n} Q_{S}\right)$ and the mass $\left(\sum_{1}^{n} Q_{f} \delta \mathrm{D}_{f}\right.$ or $\left.\sum_{1}^{n} Q_{s} \delta \mathrm{D}_{\mathrm{s}}\right)$ are influenced by rainfall recharge $I_{f}$ and

448 flow exchange $Q_{E}$. More specifically, considering vertical heterogeneity at the sites, outlet

449 flows $Q$ and mass $Q \delta \mathrm{D}$ can be expressed by: $\sum_{1}^{n} \sum_{1}^{n 1} Q_{f}+\sum_{1}^{n} \sum_{1}^{n 2} Q_{s}$ and $\sum_{1}^{n} \sum_{1}^{n 1} Q_{f} \delta D_{f}+$

$450 \quad \sum_{1}^{n} \sum_{1}^{n 2} Q_{S} \delta D_{S}$, respectively, where $\mathrm{n} 1$ and $\mathrm{n} 2$ are the respective number of permeable and less

451 permeable layers in a profile.

$452 \quad$ 4.1.2 Benefits of an integrated approach

453 Karst aquifers have distinct hydraulic structures and behaviors and therefore require

454 specific investigation methods (Goldscheider and Drew 2007). Capturing the hydrological

455 functions requires hydrometric observations and tracer sampling at sub-hourly intervals as

456 shown in our study. Current techniques that deploy loggers with the capacity to monitor in 
457 real-time and the capability to transfer data remotely are particularly useful (Luhmann et al., 458 2015). In general, monitoring water level data is easy and cheap and it reflects the relatively 459 strong control of rainfall frequency on hydrograph shape. Nevertheless, it has limited value in 10

460 interpreting karst aquifer structures (Jeannin and Sauter, 1998) and identifying the

461 contributions of event and pre-event water. The non-conservative nature of water temperature

462 facilitates insights into conduit size, and the damping and retardation in porous media via an

463 analysis of input and output thermographs (Covington et al., 2011, 2012; Luhmann et al.,

464 2012; Birk et al., 2014; Luhmann et al., 2015). However, reliable identification of the

465 hydrological functions from input and output thermographs need integrate information on

466 heat exchange within karst conduits that may introduce a retardation in the residence times

467 (Luhmann et al., 2015). Comparison of the temporary variation of isotopic values in rainfall

468 with the observed variability in karst spring waters allows not only quantification of mixing

469 processes in discharge as shown in our study, but also to quantify transit time distributions

470 (Hu et al., 2015) and determine groundwater ages.

471 Selecting representative sites is challenging and important in capturing the large-scale

472 hydrological functions in the karst catchment due to strong heterogeneity, hydraulic

473 discontinuity and anisotropy. Traditionally, tracing and hydrometric observations have been

474 mostly undertaken in the conduit network to study the rapid flow (Goldscheider et al. 2008)

475 and at outlet springs for the overall characterization of karst systems (Kovacs and Perrochet,

476 2008). However, fractured rocks in the karst critical zone have the permeability ranging over

477 several orders of magnitude. Even at small spatial scales (e.g. the four wells in our study 
478 catchment), there is relatively less active subsurface flow in the high permeability zones, and

479 relatively active subsurface flow in the less permeable zones. Additionally, our analyzed

480 results of new event water recharge and the degree of mixing with pre-event old water

481 indicates that water samples at representative depths to characterize subsurface inflows to

482 wells are necessary for assessing different flow paths in the karst and temporal changes in

483 their hydrological dynamics.

484 A key contribution of this study was to show how geophysical techniques like ERT

485 surveys can help identifying structural differences which can be incorporated in designing

486 targeted monitoring networks. ERT images combined with tracer characteristics of subsurface

487 water and the associated mixing processes identify which depths/sites in the catchment are

488 representative for monitoring in order to reliably quantify fast and slow flows. As shown in

489 Fig 8, water sampling at permeable layers/sites during rainfall events are required for

490 capturing variability of the hydrological functions in the karst catchment. If the permeability

491 varies with depth, water sampling at various depths are particularly important for quantifying

492 the depth-dependent variability of the hydrological function.

493 Moreover, ERT images combined with details observations provide insights into how to

494 conceptualize complex karst systems for lumped and distributed modeling. ERT images

495 provide high-resolution visualization of the subsurface, and the relationship between these

496 images and parameters affecting flow and transport (Hubbard et al., 1999). The spatially

497 distributed information from geophysics and isotopic characterisation of subsurface water and

498 the associated mixing processes facilitate tracing water flow sources (e.g. rainfall recharge 
and exchange between high and low permeable sites/layers). This understanding can inform

500 hydrological model structures at different scales (e.g. as conceptualized fast and slow flow

501 reservoirs) and their hydrological connectivity (e.g. hillslope-depression-outlet). The inferred

502 hydrologic characteristics can be then used either independently or combined with direct

503 hydrologic observations to constrain hydrologic properties and reduce uncertainty in

504 hydrological models (Hinnell et al., 2010).

\section{$505 \quad 4.2$ Conclusions}

506 Understanding the function of the water cycle is a key issue for critical zone science

507 since water is a unifying theme for understanding complex environmental systems (Lin, 2010).

508 Nevertheless, it is a significant challenge to identify active subsurface processes that

509 determine water flows and travel times. In this study, geophysical, hydrometric and tracer

510 tools are used to characterize the hydrological function of the cockpit karst critical zone in the

511 small catchment of Chenqi, Guizhou province, China. The ERT surveys (Fig 2) identified

512 structural features that likely control aquifer permeability and the heterogeneity in observed

513 hydrodynamic response. Hydrometric observations and using water temperatures (Figs 2 and

5143 3) as a tracer clearly identified rainfall recharge and flow recession induced by new rainwater

515 recharge and the constraints of aquifer permeability. Stable water isotopes $\left(\delta \mathrm{D}\right.$ and $\left.\delta^{18} \mathrm{O}\right)($ Fig

516 5) largely corroborated geophysical, hydrometric and thermal data and provided detail

517 qualitative insight into event water recharge into, and pre-event storage release from, the 518 heterogeneous aquifer. In particular, this information can help identify flow paths of new 
519 event water recharging through high permeability zones in both horizontal and vertical
520 directions in the catchment.

521 The study illustrated that even in a highly heterogeneous catchment, hydrological functions

522 can be conceptualized simply into fast and slow flow reservoirs. Nevertheless, using such a

523 dual flow system in simulation of hydrological processes should be based on detail

524 observations at representative sites within a catchment. Particularly, since hydrological

525 functions can vary with depth, observations and water sampling from various permeability

526 layers are extremely important.

\section{Acknowledgments}

528 This research was supported by The UK-China Critical Zone Observatory (CZO)

529 Programme (41571130071), the National Natural Scientific Foundation of China (41571020),

530 National 973 Program of China (2015CB452701), the National Key Research and

531 development Program of China (2016YFC0502602), the Fundamental Research Funds for the

532 Central Universities (2016B04814) and the UK Natural Environment Research Council

533 (NE/N007425/1 \& NE/N007409/1). We thank the editor and the two anonymous reviewers

534 for their constructive comments on the earlier manuscript, which lead to an improvement of

535 the paper.

536

537 


\section{REFERENCES}

539 Anderson MP. 2005. Heat as a ground water tracer. Ground Water 43 (6): 951-968 DOI:

$540 \quad 10.1111 / \mathrm{j} .1745-6584.2005 .00052 . \mathrm{x}$

541 Aquilina L, Ladouche B, Dörfliger N. 2006. Water storage and transfer in the epikarst of

542 karstic systems during high flow periods. Journal of Hydrology 327 (3-4): 472-485 DOI:

$543 \quad$ 10.1016/j.jhydrol.2005.11.054

544 Barberá JA, Andreo B. 2012. Functioning of a karst aquifer from S Spain under highly

545 variable climate conditions, deduced from hydrochemical records. Environmental Earth

546 Sciences 65 (8): 2337-2349 DOI: 10.1007/s12665-011-1382-4

547 Batiot C, Emblanch C, Blavoux B. 2003. Total Organic Carbon (TOC) and magnesium

$548(\mathrm{Mg} 2+)$ : two complementary tracers of residence time in karstic systems. Comptes Rendus

549 Geoscience 335 (2): 205-214 DOI: 10.1016/S1361-0713(03)00027-0

550 Becker MW, Georgian T, Ambrose H, Siniscalchi J, Fredrick K. 2004. Estimating flow and

551 flux of ground water discharge using water temperature and velocity. Journal of Hydrology

552296 (1-4): 221-233 DOI: 10.1016/j.jhydrol.2004.03.025

553 Binley, A, 2015, Tools and Techniques: DC Electrical Methods, In: Treatise on Geophysics, 554 2nd Edition, G Schubert (Ed.), Elsevier., Vol. 11, 233-259, 555 doi:10.1016/B978-0-444-53802-4.00192-5.

556 Binley A, Hubbard SS, Huisman JA, Revil A, Robinson DA, Singha K, Slater LD. 2015. The 557 emergence of hydrogeophysics for improved understanding of subsurface processes over 
558 multiple scales, Water Resources Research, 51(6), 3837-3866, 559 DOI:10.1002/2015WR017016

560 Biswas H, Sena DR, Kumar G, Lakaria BL, Raizada A, Kumar S, Mishra PK. 2017. Effect of

561 water storage structures on groundwater recharge in India. Groundwater for Sustainable

562 Development 4: 49-56 DOI: 10.1016/j.gsd.2017.01.002

563 Birk S, Wagner T, Mayaud C. 2014. Threshold behavior of karst aquifers: The example of the

564 Lurbach karst system (Austria). Environmental Earth Sciences 72 (5): 1349-1356 DOI:

$565 \quad 10.1007 / \mathrm{s} 12665-014-3122-\mathrm{z}$

566 Carrière SD, Chalikakis K, Sénéchal G, Danquigny C, Emblanch C. 2013. Combining

567 Electrical Resistivity Tomography and Ground Penetrating Radar to study geological

568 structuring of karst Unsaturated Zone. Journal of Applied Geophysics 94: 31-41 DOI:

$569 \quad$ 10.1016/j.jappgeo.2013.03.014

570 Chalikakis K, Plagnes V, Guerin R, Valois R, Bosch FP. 2011. Contribution of geophysical

571 methods to karst-system exploration: An overview. Hydrogeology Journal 19 (6): 1169-

5721180 DOI: $10.1007 / \mathrm{s} 10040-011-0746-\mathrm{X}$

573 Coplen TB. 1994. Reporting of stable hydrogen, carbon, and oxygen isotopic abundances

574 (Technical Report). Pure and Applied Chemistry 66 (2): 273-276 DOI:

$575 \quad 10.1351 / \mathrm{pac} 199466020273$.

576 Covington MD, Luhmann AJ, Gabrovek F, Saar MO, Wicks CM. 2011. Mechanisms of heat

577 exchange between water and rock in karst conduits. Water Resources Research 47 (10) DOI:

$578 \quad 10.1029 / 2011$ WR010683.

28

http://mc.manuscriptcentral.com/hyp 
579

580 Covington MD, Luhmann AJ, Wicks CM, Saar MO. 2012. Process length scales and 581 longitudinal damping in karst conduits. Journal of Geophysical Research: Earth Surface 117 582 (1) DOI: 10.1029/2011JF002212.

583 Emblanch C, Zuppi GM, Mudry J, Blavoux B, Batiot C. 2003. Carbon 13 of TDIC to quantify 584 the role of the unsaturated zone: The example of the Vaucluse karst systems (Southeastern 585 France). Journal of Hydrology 279 (1-4): 262-274 DOI: 10.1016/S0022-1694(03)00180-X

586 Fan J, Oestergaard KT, Guyot A, Lockington DA. 2014. Estimating groundwater recharge 587 and evapotranspiration from water table fluctuations under three vegetation covers in a 588 coastal sandy aquifer of subtropical Australia. Journal of Hydrology 519 (PA): 1120-1129 589 DOI: $10.1016 /$ j.jhydrol.2014.08.039

590 Field MS. 1993. Karst Hydrology and Chemical Contamination. Journal of Environmental 591 Systems 22 (1): 1-26 DOI: 10.2190/X7MV-C93E-66GK-BFH7

592 Ford D, Williams P. 2013. Karst Hydrogeology and Geomorphology. DOI: $593 \quad 10.1002 / 9781118684986$

594 Goldscheider N, Drew D. 2007. Methods in Karst Hydrogeology. Taylor \& Francis Group, 595 Leiden, NL.

596 Hartmann A, Goldscheider N, Wagener T, Lange J, Weiler M. 2014. Karst water resources in 597 a changing world: Approaches, of hydrological modeling. Review of Geophysics (1): 1-25 598 DOI: 10.1002/2013RG000443 
599 Healy RW, Cook PG. 2002. Using groundwater levels to estimate recharge. Hydrogeology

600 Journal 10 (1): 91-109 DOI: 10.1007/s10040-001-0178-0

601 Hinnell AC, Ferr TPA, Vrugt JA, Huisman JA, Moysey S, Rings J, Kowalsky MB. 2010.

602 Improved extraction of hydrologic information from geophysical data through coupled

603 hydrogeophysical inversion. Water Resources Research 46 (4) DOI:

$604 \quad 10.1029 / 2008 W R 007060$.

$605 \mathrm{Hu}$ K, Chen H, Nie Y, Wang K. 2015. Seasonal recharge and mean residence times of soil 606 and epikarst water in a small karst catchment of southwest China. Scientific Reports 5 DOI:

$607 \quad 10.1038 /$ srep 10215.

608 Hubbard SS, Rubin Y, Majer E. 1999. Spatial correlation structure estimation using

609 geophysical and hydrogeological data. Water Resources Research 35 (6): 1809-1825 DOI:

$610 \quad 10.1029 / 1999 W R 900040$.

611 Hyman JD, Painter SL, Viswanathan H, Makedonska N, Karra S. 2015. Influence of injection

612 mode on transport properties in kilometer-scale three-dimensional discrete fracture networks.

613 Water Resources Research 51 (9): 7289-7308 DOI: 10.1002/2015WR017151.

614 Irvine DJ, Cranswick RH, Simmons CT, Shanafield MA, Lautz LK. 2015. The effect of

615 streambed heterogeneity on groundwater-surface water exchange fluxes inferred from

616 temperature time series. Water Resources Research 51 (1): 198-212 DOI:

$617 \quad 10.1002 / 2014$ WR015769

618 Jeannin PY, Sauter M. 1998. Analysis of karst hydrodynamic behaviour using global 619 approaches: A review. Bull/d'Hydrogéologie 16: 31-48. 
620 Jiang G, Guo F, Wu J, Li H, Sun H. 2008. The threshold value of epikarst runoff in forest 621 karst mountain area. Environmental Geology 55 (1): 87-93 DOI: $622 \quad 10.1007 / \mathrm{s} 00254-007-0967-4$.

623 Kovács A, Sauter M. 2007. Modelling karst hydrodynamics. In: Goldscheider N, Drew D 624 (eds) Methods in karst hydrogeology, vol 26. International Contribution to Hydrogeology, 625 Heise, Hanover, Germany, pp 201-220

626 Lee LJE, Lawrence DSL, Price M. 2006. Analysis of water-level response to rainfall and 627 implications for recharge pathways in the Chalk aquifer, SE England. Journal of Hydrology 628330 (3-4): 604-620 DOI: 10.1016/j.jhydrol.2006.04.025

629 Lin H. 2010. Earth's Critical Zone and hydropedology: concepts, characteristics, and 630 advances. Hydrol. Earth Syst. Sci., 14, 25-45

631 Long JCS, Remer JS, Wilson CR, Witherspoon PA. 1982. Porous media equivalents for 632 networks of discontinuous fractures. Water Resources Research 18 (3): 645-658 DOI: 633 10.1029/WR018i003p00645.

634 Long AJ, Putnam LD. 2004. Linear model describing three components of flow in karst 635 aquifers using 180 data. Journal of Hydrology 296 (1-4): 254-270 DOI: $636 \quad 10.1016 / \mathrm{j} . j$ hydrol.2004.03.023

637 Lowry CS, Walker JF, Hunt RJ, Anderson MP. 2007. Identifying spatial variability of 638 groundwater discharge in a wetland stream using a distributed temperature sensor. Water 639 Resources Research 43 (10) DOI: 10.1029/2007WR006145 
640 Luhmann AJ, Covington MD, Alexander SC, Chai SY, Schwartz BF, Groten JT, Alexander

641 EC. 2012. Comparing conservative and nonconservative tracers in karst and using them to

642 estimate flow path geometry. Journal of Hydrology 448-449: 201-211 DOI:

$643 \quad$ 10.1016/j.jhydrol.2012.04.044.

644 Luhmann AJ, Covington MD, Myre JM, Perne M, Jones SW, Alexander EC, Saar MO. 2015.

645 Thermal damping and retardation in karst conduits. Hydrology and Earth System Sciences

64619 (1): 137-157 DOI: 10.5194/hess-19-137-2015.

647 Martínez-Moreno FJ, Galindo-Zaldívar J, Pedrera A, Teixido

648 T, Ruano P, Peña JA, González-Castillo L, Ruiz-Constán A, López-Chicano M, 649 Martín-Rosales W. 2014. Integrated geophysical methods for studying the karst system of 650 Gruta de las Maravillas (Aracena, Southwest Spain). Journal of Applied Geophysics 107:

651 149-162 DOI: 10.1016/j.jappgeo.2014.05.021

652 Mudarra M, Andreo B, Marín AI, Vadillo I, Barberá JA. 2014. Combined use of natural and 653 artificial tracers to determine the hydrogeological functioning of a karst aquifer: the 654 Villanueva del Rosario system (Andalusia, southern Spain). Hydrogeology Journal 22 (5): 655 1027-1039 DOI: 10.1007/s10040-014-1117-1

656 Mudarra M, Andreo B. 2011. Relative importance of the saturated and the unsaturated zones 657 in the hydrogeological functioning of karst aquifers: The case of Alta Cadena (Southern 658 Spain). Journal of Hydrology 397 (3-4): 263-280 DOI: 10.1016/j.jhydrol.2010.12.005 
659 Niswonger RG, Prudic DE, Pohll G, Constantz J. 2005. Incorporating seepage losses into the 660 unsteady streamflow equations for simulating intermittent flow along mountain front streams. 661 Water Resources Research 41 (6): 1-16 DOI: 10.1029/2004WR003677.

662 Perrin J, Jeannin PY, Zwahlen F. 2003. Epikarst storage in a karst aquifer: A conceptual 663 model based on isotopic data, Milandre test site, Switzerland. Journal of Hydrology 279 (1664 4): 106-124 DOI: 10.1016/S0022-1694(03)00171-9.

665 Plummer LN, Busenberg E, McConnell JB, Drenkard S, Schlosser P, Michel RL. 1998. Flow 666 of river water into a Karstic limestone aquifer. 1. Tracing the young fraction in groundwater 667 mixtures in the Upper Floridan Aquifer near Valdosta, Georgia. Applied Geochemistry 13 668 (8): 995-1015 DOI: 10.1016/S0883-2927(98)00031-6

669 Rau GC, Andersen MS, McCallum AM, Acworth RI. 2010. Analytical methods that use 670 natural heat as a tracer to quantify surface water-groundwater exchange, evaluated using 671 field temperature records. Hydrogeology Journal 18 (5): 1093-1110 DOI: $672 \quad 10.1007 / \mathrm{s} 10040-010-0586-0$

673 Rau GC, Andersen MS, McCallum AM, Roshan H, Acworth RI. 2014. Heat as a tracer to 674 quantify water flow in near-surface sediments. Earth-Science Reviews 129: 40-58 DOI: $675 \quad$ 10.1016/j.earscirev.2013.10.015

676 Sophocleous M. 2002. Interactions between groundwater and surface water: The state of the 677 science. Hydrogeology Journal 10 (1): 52-67 DOI: 10.1007/s10040-001-0170-8 
678 Sophocleous MA. 1991. Combining the soilwater balance and water-level fluctuation 679 methods to estimate natural groundwater recharge: Practical aspects. Journal of Hydrology 680124 (3-4): 229-241 DOI: 10.1016/0022-1694(91)90016-B

681 Soulsby C, Bradford J, Dick J, McNamara JP, Geris J, Lessels J, Blumstock M, Tetzlaff D. 682 2016. Using geophysical surveys to test tracer-based storage estimates in headwater 683 catchments. Hydrological Processes 30 (23): 4434-4445 DOI: 10.1002/hyp.10889

684 Sprenger M, Tetzlaff D, Soulsby C. 2017. Soil water stable isotopes reveal evaporation 685 dynamics at the soil-plant-atmosphere interface of the critical zone. Hydrology and Earth 686 System Sciences 21 (7): 3839-3856 DOI: 10.5194/hess-21-3839-2017

687 Sprenger M. Tetzlaff D, Buttle JM, Snelgrove J, Laudon H, Mitchell C, Weiler M, Soulsby C. 688 2018. Measuring and modelling stable isotopes of mobile and bulk soil water. Vadose Zone 689 Journal. DOI: 10.2136/vzj2017.08.0149.

690 Sun Z, Ma R, Wang Y, Ma T, Liu Y. 2016. Using isotopic, hydrogeochemical-tracer and 691 temperature data to characterize recharge and flow paths in a complex karst groundwater 692 flow system in northern China. Hydrogeology Journal 24 (6): 1393-1412 DOI: $693 \quad 10.1007 / \mathrm{s} 10040-016-1390-2$

694 Winter TC. 1999. Relation of streams, lakes, and wetlands to groundwater flow systems. 695 Hydrogeology Journal 7 (1): 28-45 DOI: 10.1007/s100400050178

696 Xie Z, Yuan X. 2010. Prediction of water table under stream-aquifer interactions over an arid 697 region. Hydrological Processes 24 (2): 160-169 DOI: 10.1002/hyp.7434 
698 Williams PW. 1983. The role of the subcutaneous zone in karst hydrology. Journal of 699 Hydrology 61 (1-3): 45-67 DOI: 10.1016/0022-1694(83)90234-2.

700 Worthington SRH, Jeannin P-Y, Alexander EC, Davies GJ, Schindel GM. 2017. Contrasting

701 definitions for the term 'karst aquifer'. Hydrogeology Journal 25 (5): 1237-1240 DOI:

$702 \quad 10.1007 / \mathrm{s} 10040-017-1628-7$.

703 Zhang Z, Chen X, Chen X, Shi P. 2013. Quantifying time lag of epikarst-spring hydrograph

704 response to rainfall using correlation and spectral analyses. Hydrogeology Journal 21 (7):

705 1619-1631 DOI: 10.1007/s10040-013-1041-9.

706 Zhang Z, Chen X, Soulsby C. 2017. Catchment-scale conceptual modelling of water and 707 solute transport in the dual flow system of the karst critical zone. Hydrological Processes 31 708 (19): 3421-3436 DOI: 10.1002/hyp.11268 709 
Table 1 Statistical summary of water level and flow discharge

\begin{tabular}{ccccccc}
\hline & \multicolumn{2}{c}{ Water Level $(\mathrm{m})$} & \multicolumn{2}{c}{ Flow discharge $\left(\mathrm{m}^{3} / \mathrm{s}\right)$} \\
\hline Min & W1 & W3 & W4 & W5 & Hillslope & Outlet \\
Max & 1267.4 & 1272.6 & 1280.0 & 1276.4 & 0 & 0 \\
Range & 1275.9 & 1279.9 & 1285.2 & 1284.0 & $1.4 \times 10^{-3}$ & 0.15 \\
Mean & 1273.6 & 1275.9 & 1281.8 & 1278.9 & $8.5 \times 10^{-5}$ & $4.7 \times 10^{-3}$ \\
Cv & 0.03 & 0.21 & 0.61 & 0.07 & 1.73 & 2.83 \\
\hline
\end{tabular}


Table 2 Statistical summary of air and water temperature

\begin{tabular}{rccccccc}
\hline & Air & W1 & W3 & W4 & W5 & Hillslope & Outlet \\
\hline $\mathrm{T}_{\min }{ }^{\circ} \mathrm{C}$ & 0 & 17.2 & 16.4 & 16.1 & 16.8 & 8.8 & 14.1 \\
$\mathrm{~T}_{\max }{ }^{\circ} \mathrm{C}$ & 35.6 & 17.5 & 22 & 19.6 & 17.5 & 21.1 & 21.3 \\
Range & 35.6 & 0.3 & 5.6 & 3.5 & 0.7 & 12.3 & 7.2 \\
$\mathrm{~T}_{\text {mean }}{ }^{\circ} \mathrm{C}$ & 16.8 & 17.3 & 17.9 & 17.3 & 17.1 & 16.8 & 17.1 \\
$\mathrm{Cv}$ & 0.421 & 0.004 & 0.026 & 0.036 & 0.012 & 0.16 & 0.08 \\
\hline
\end{tabular}


Table 3 Statistical summary of isotope data for rainfall, hillslope spring (HS), catchment outlet and depression wells

\begin{tabular}{cccccccccccc}
\hline \multirow{2}{*}{ Obs } & \multirow{2}{*}{ Period } & \multicolumn{4}{c}{$\delta \mathrm{D}(\%)$} \\
\cline { 3 - 11 } & & Max & Min & Range & $\mathrm{Cv}$ & Mean & Max & Min & Range & $\mathrm{Cv}$ & Mean \\
\hline Rainfall & $12 / 6 \sim 13 / 8$ & -17.9 & -120.2 & -102.3 & -0.30 & -73.2 & 0 & -16.4 & -16.4 & -0.29 & -9.9 \\
outlet & $12 / 6 \sim 14 / 8$ & -46.9 & -73.1 & -26.2 & -0.06 & -61.9 & -5.1 & -10.6 & -5.5 & -0.09 & -8.7 \\
HS & $12 / 6 \sim 14 / 8$ & -51.8 & -77 & -25.2 & -0.04 & -64.3 & -5.9 & -10.8 & -4.9 & -0.06 & -9.3 \\
W1 & $6 / 7 \sim 20 / 8$ & -50.7 & -65.7 & -15 & -0.03 & -60.8 & -6.3 & -9.6 & -3.3 & -0.05 & -8.7 \\
W3 & $6 / 7 \sim 20 / 8$ & -56.1 & -73.6 & -17.5 & -0.06 & -62.4 & -7.4 & -10 & -2.6 & -0.06 & -8.7 \\
W4 & $6 / 7 \sim 20 / 8$ & -55 & -70.2 & -15.2 & -0.07 & -62.5 & -7.9 & -10.1 & -2.2 & -0.07 & -8.9 \\
W5 & $6 / 7 \sim 20 / 8$ & -55.7 & -67.5 & -11.8 & -0.03 & -58.7 & -7.9 & -10.1 & -2.2 & -0.04 & -8.5 \\
\hline
\end{tabular}




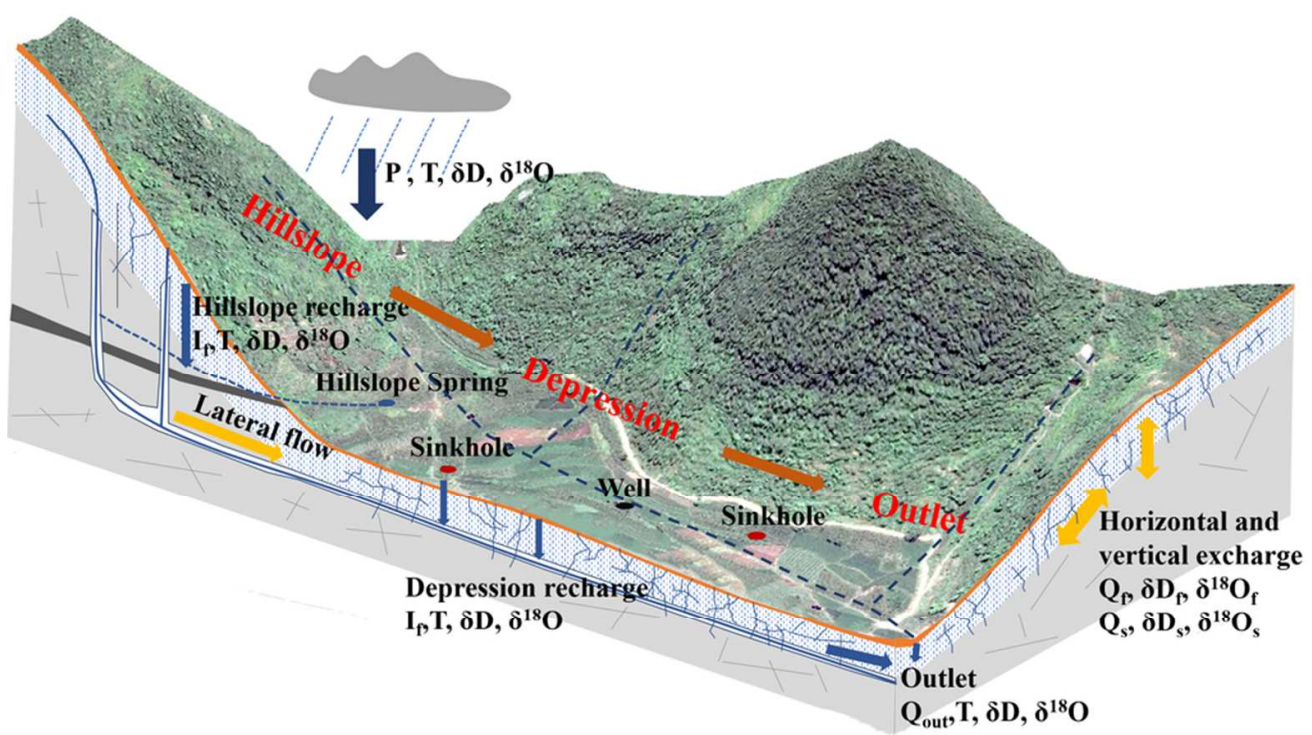

Figure 1 Sketch map of karst hydrological processes.

$43 \times 24 \mathrm{~mm}(600 \times 600$ DPI $)$ 


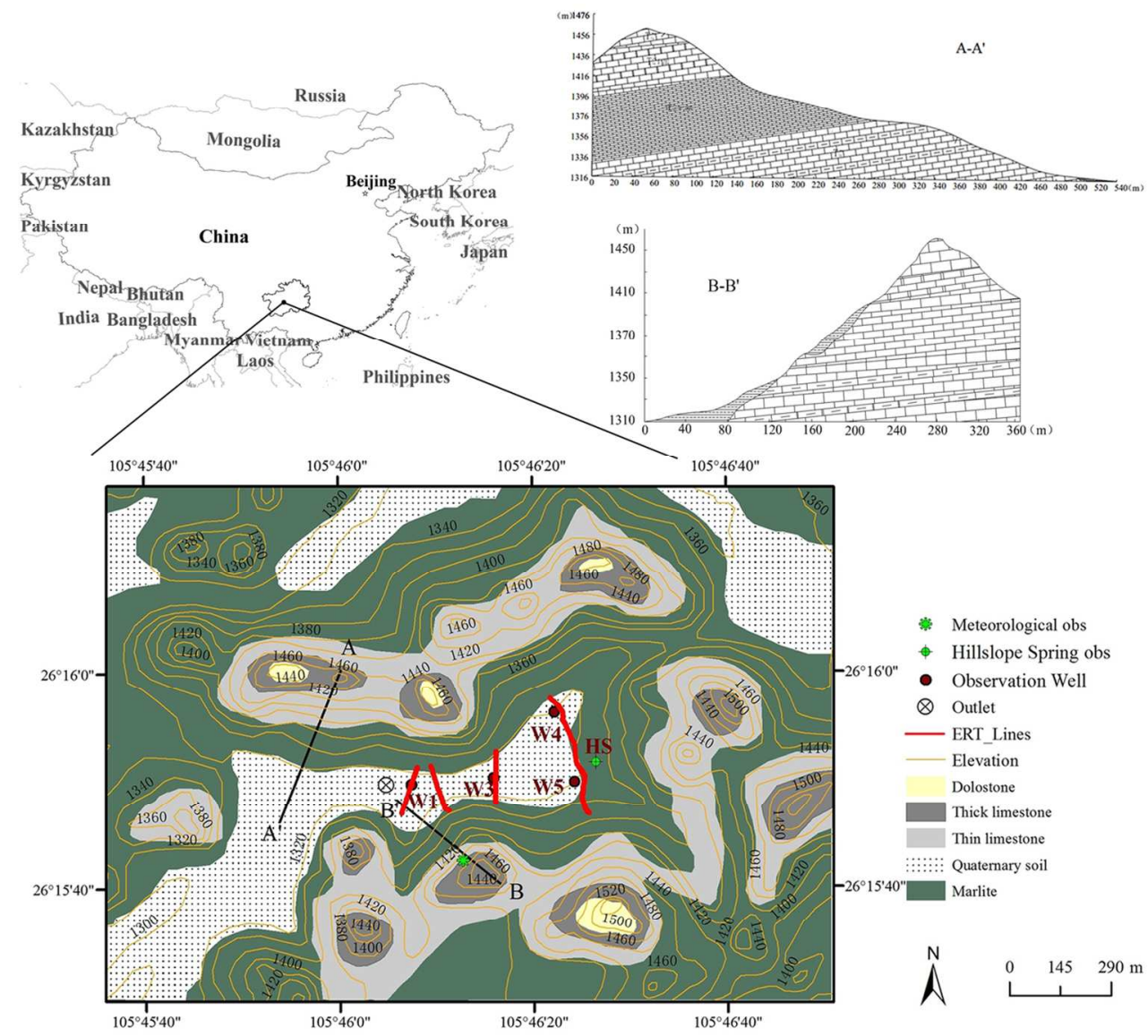

Figure 2 Map of geomorphology and hydrological monitoring locations in the Chenqi catchment. $59 \times 53 \mathrm{~mm}(600 \times 600 \mathrm{DPI})$ 


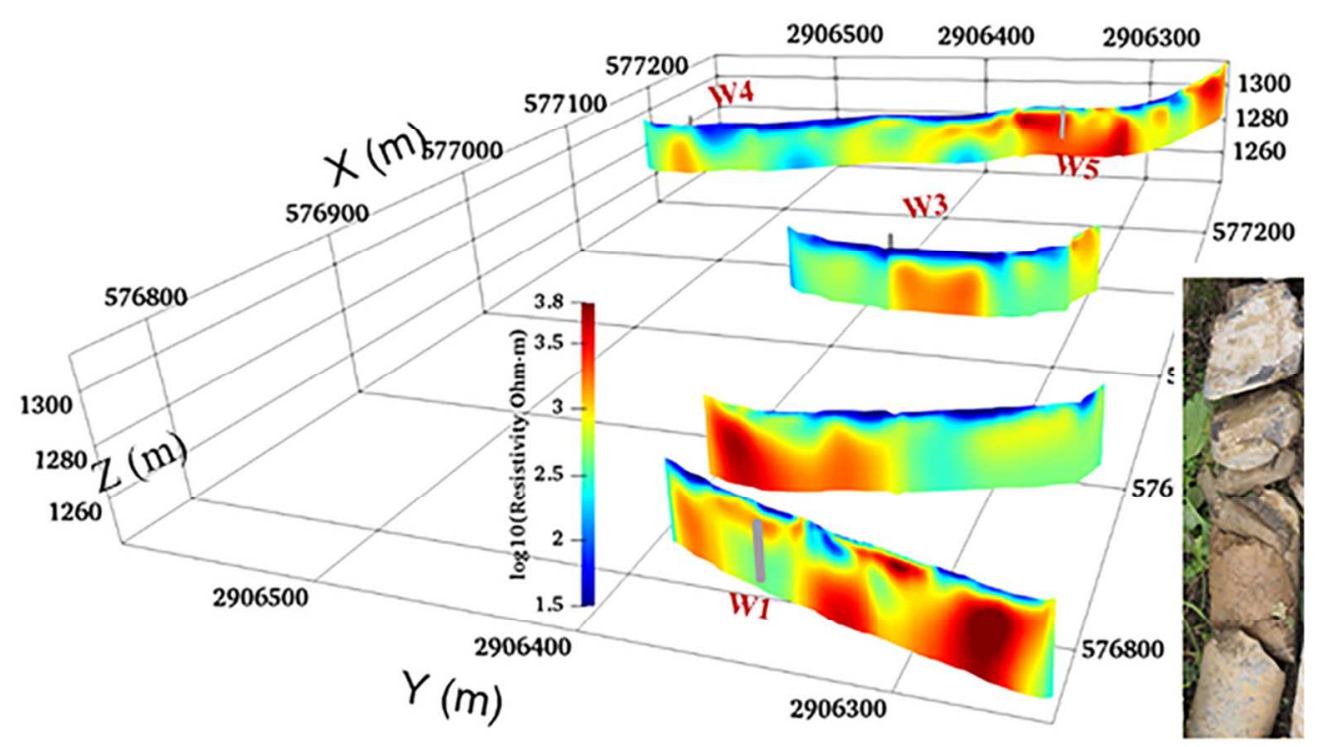

Figure 3 ERT image in the study depression corresponding to the survey profiles in Fig 1. $37 \times 21 \mathrm{~mm}(600 \times 600 \mathrm{DPI})$ 

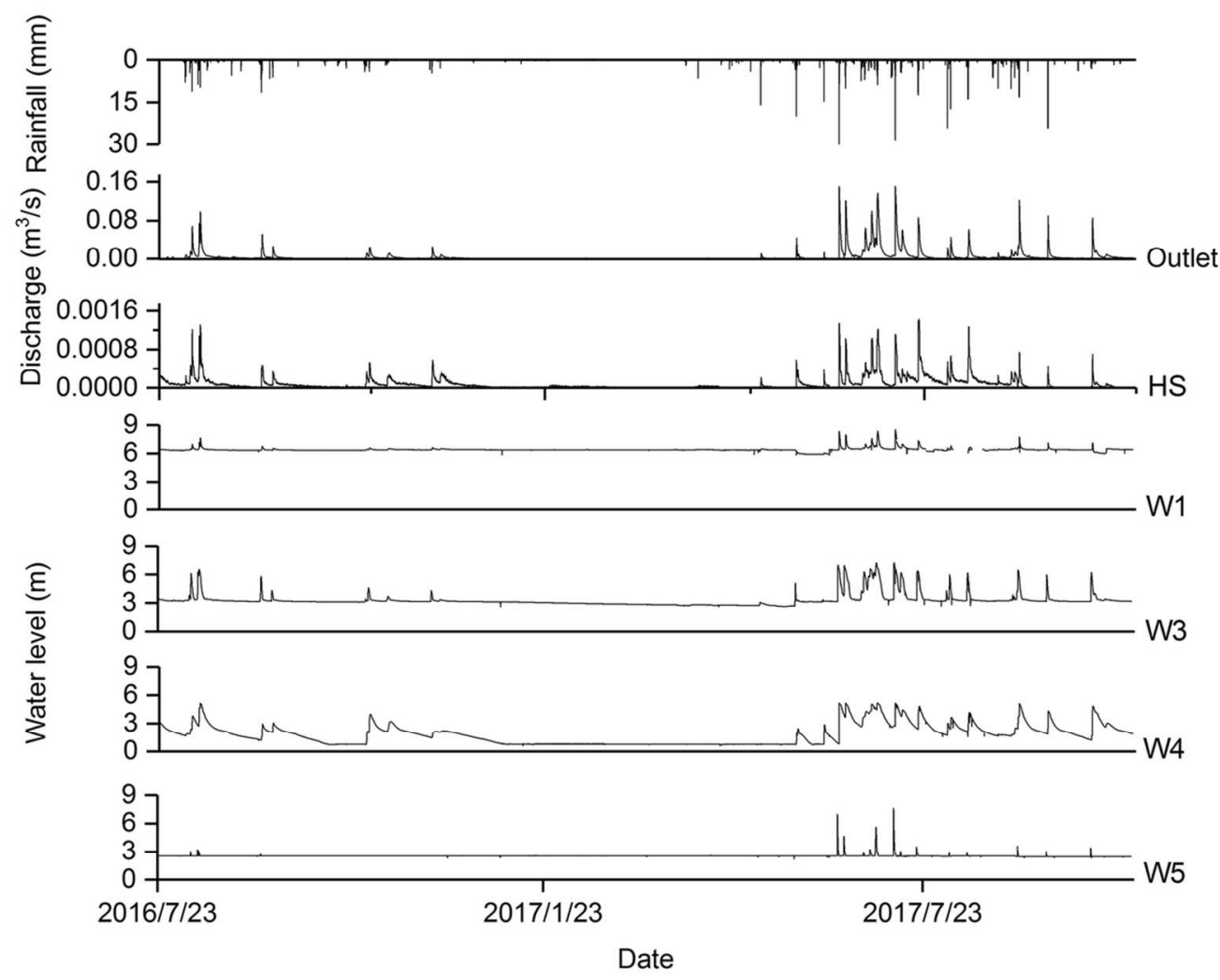

Figure 4 Variations of flow discharge for hillslope spring (HS) and catchment outlet and water levels at depression wells (W1, W3, W4 and W5).

$52 \times 41 \mathrm{~mm}(600 \times 600 \mathrm{DPI})$ 


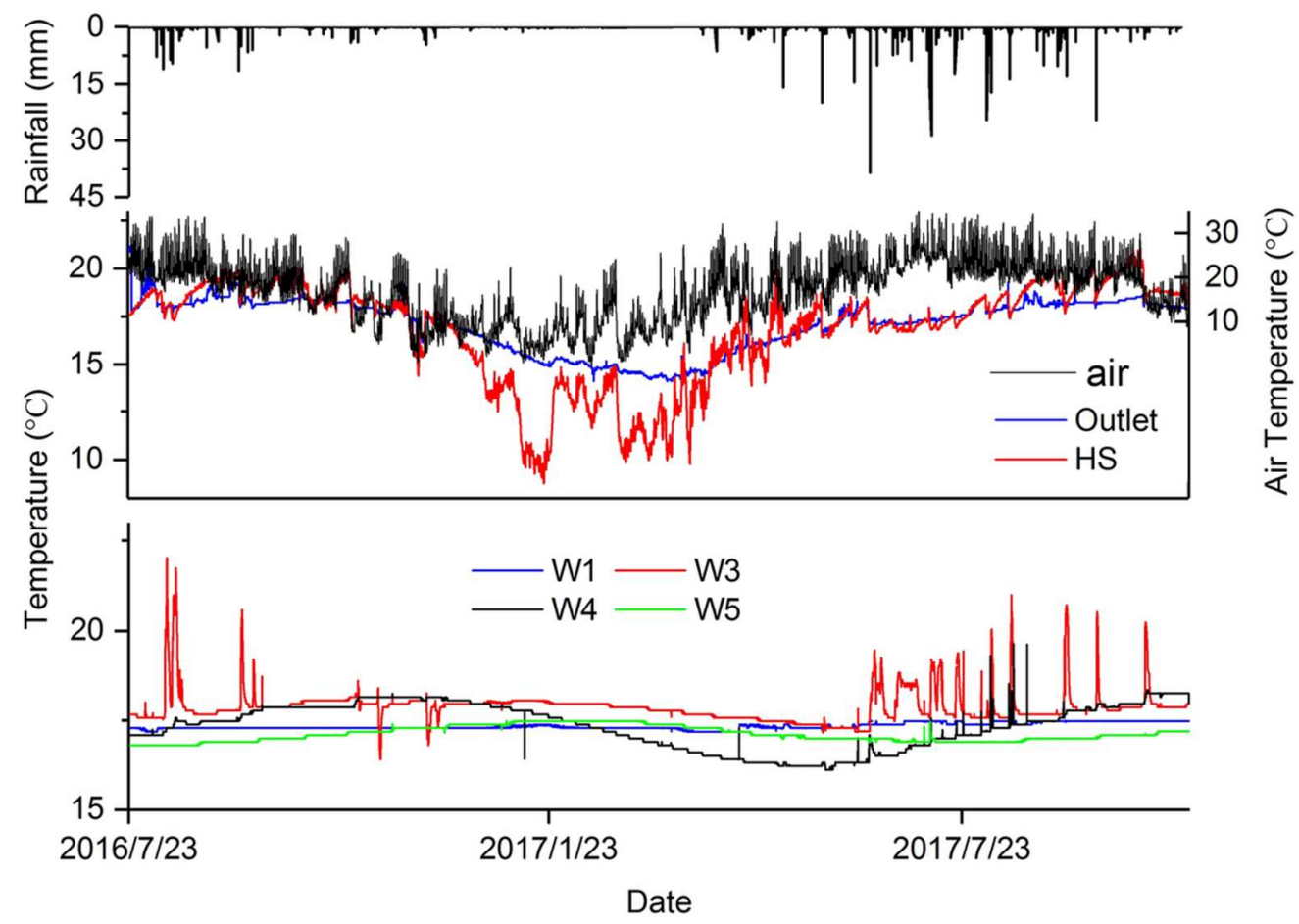

Figure 5 Variations of air temperature and water temperatures for hillslope spring (HS), outlet discharge and depression wells (W1, W3, W4 and W5).

$46 \times 33 \mathrm{~mm}(600 \times 600 \mathrm{DPI})$ 


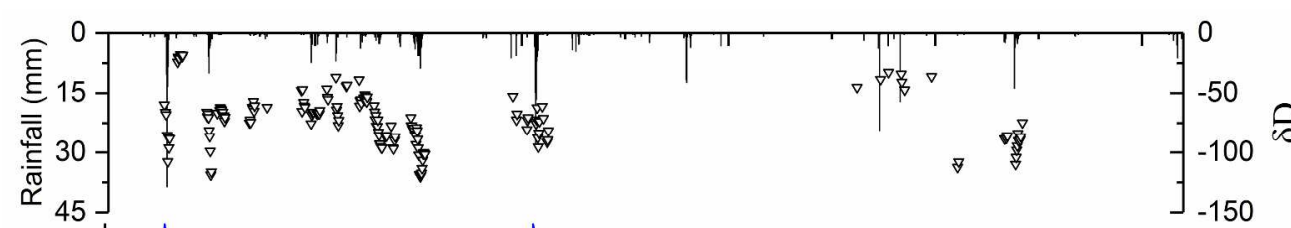

Figure 6 Variation of the $\delta \mathrm{D}$ values for rainfall, hillslope spring (HS), catchment outlet and depression wells. $148 \times 113 \mathrm{~mm}(600 \times 600 \mathrm{DPI})$ 


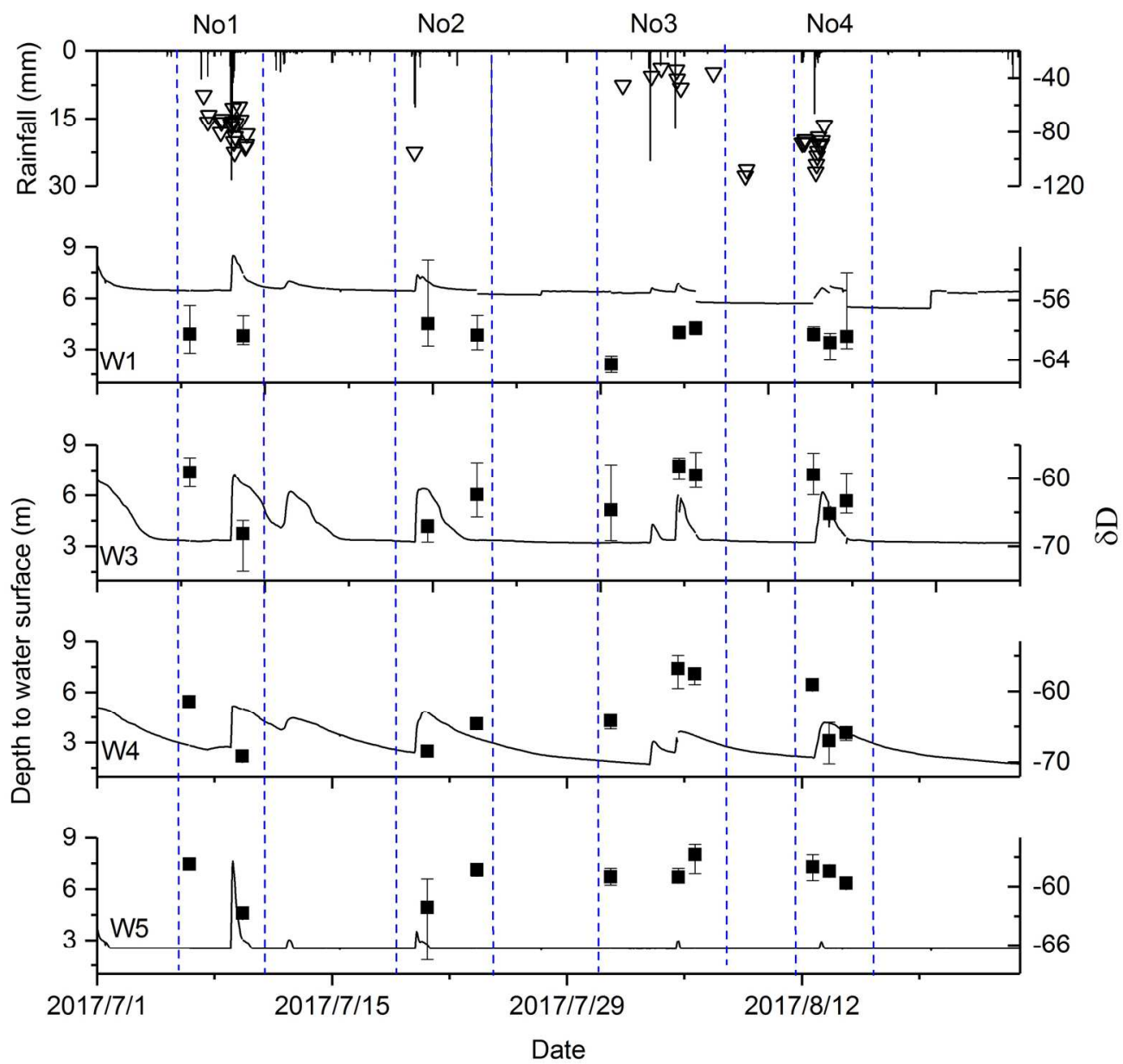

Figure 7 Variability of the $\delta D$ values for depression wells (the bar represents range of $\delta D$ values along various depths to water surface; black block represents its mean value; solid line represents depth to water table).

$85 \times 80 \mathrm{~mm}(600 \times 600 \mathrm{DPI})$ 


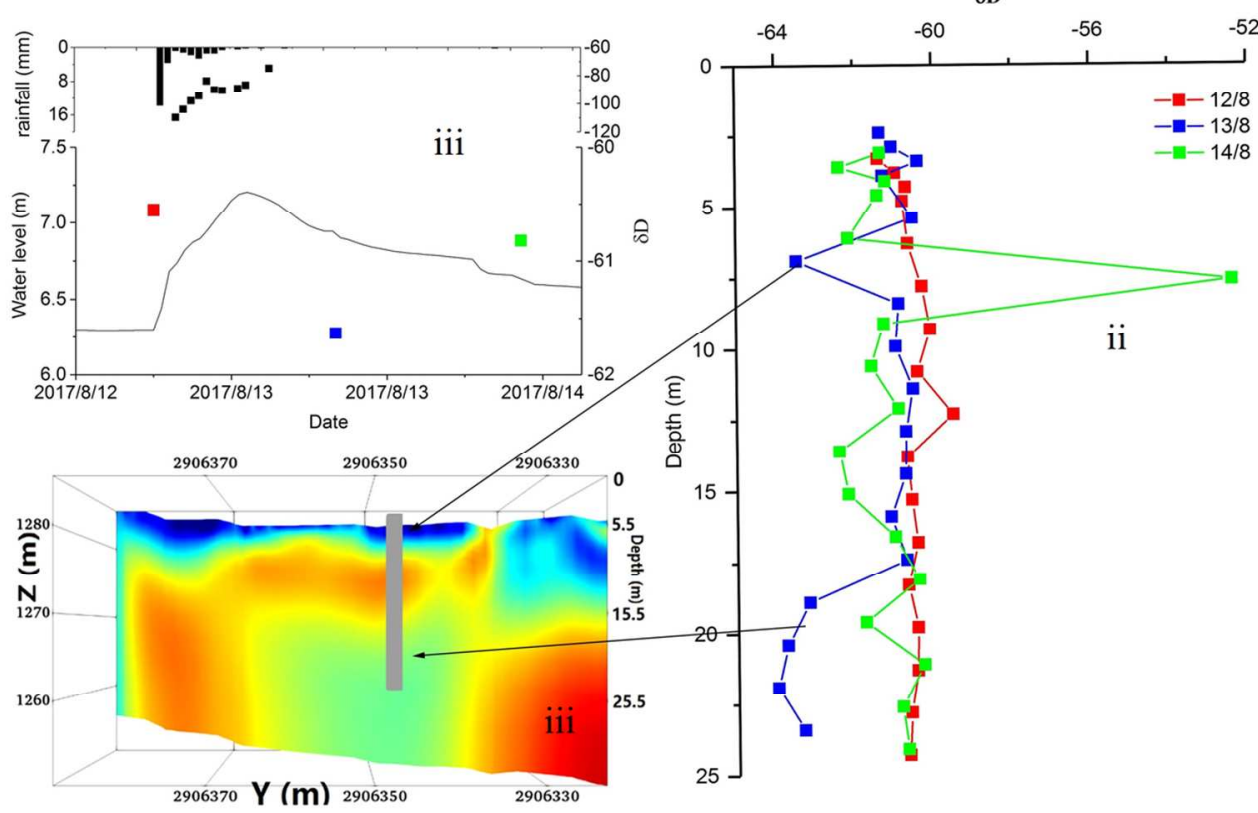

(a)

$54 \times 35 \mathrm{~mm}(600 \times 600$ DPI $)$ 


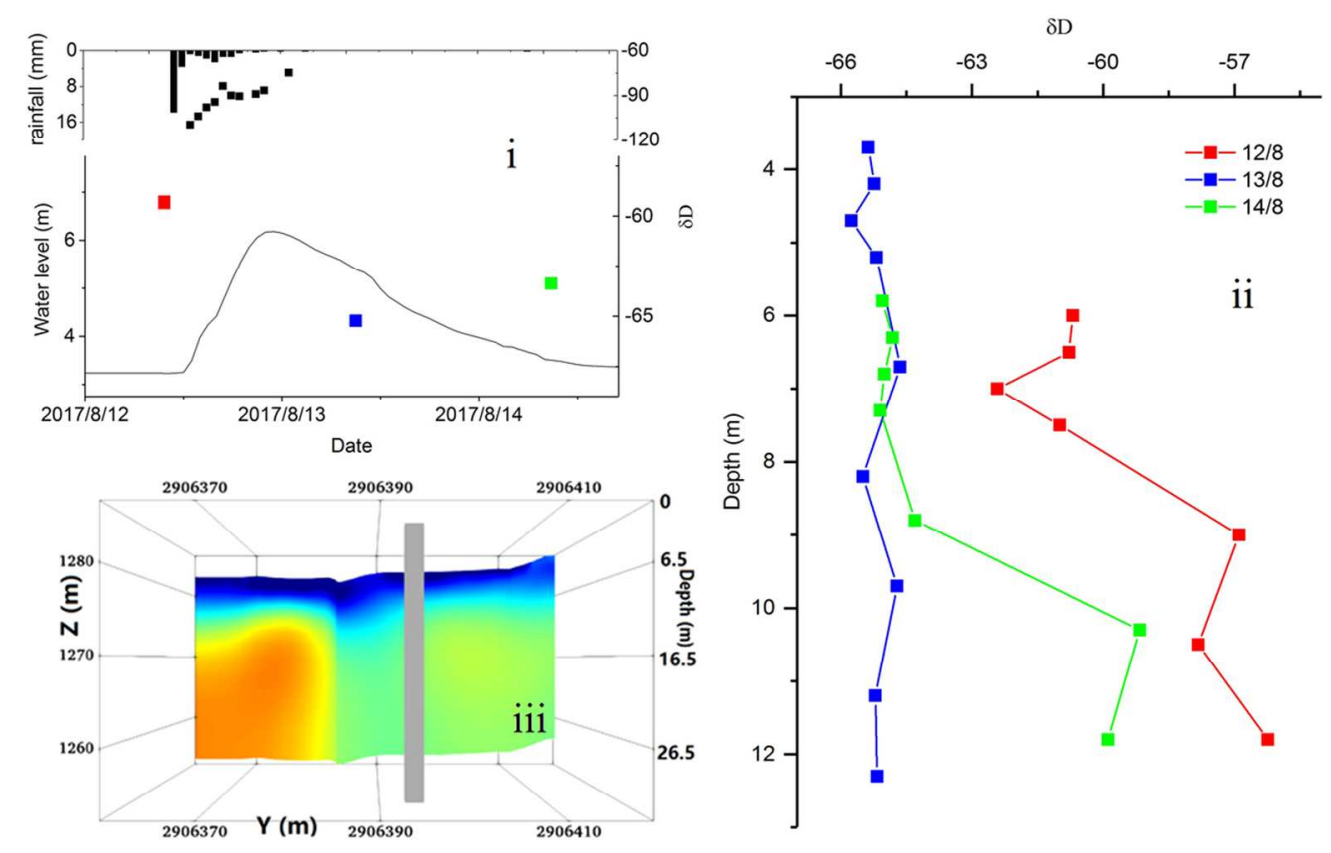

(b)

$52 \times 36 \mathrm{~mm}(600 \times 600 \mathrm{DPI})$ 

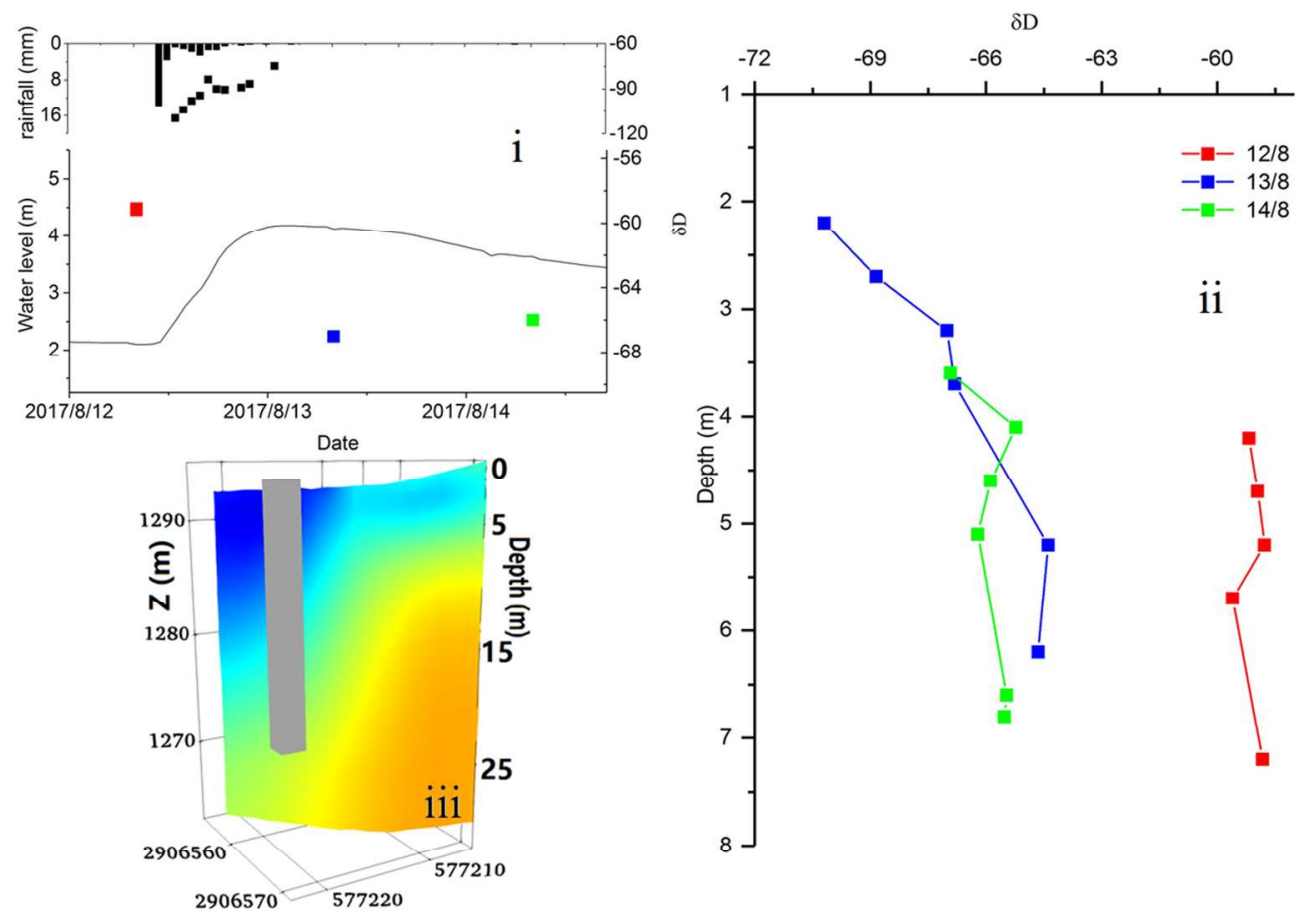

(c)

$51 \times 39 \mathrm{~mm}(600 \times 600$ DPI $)$ 


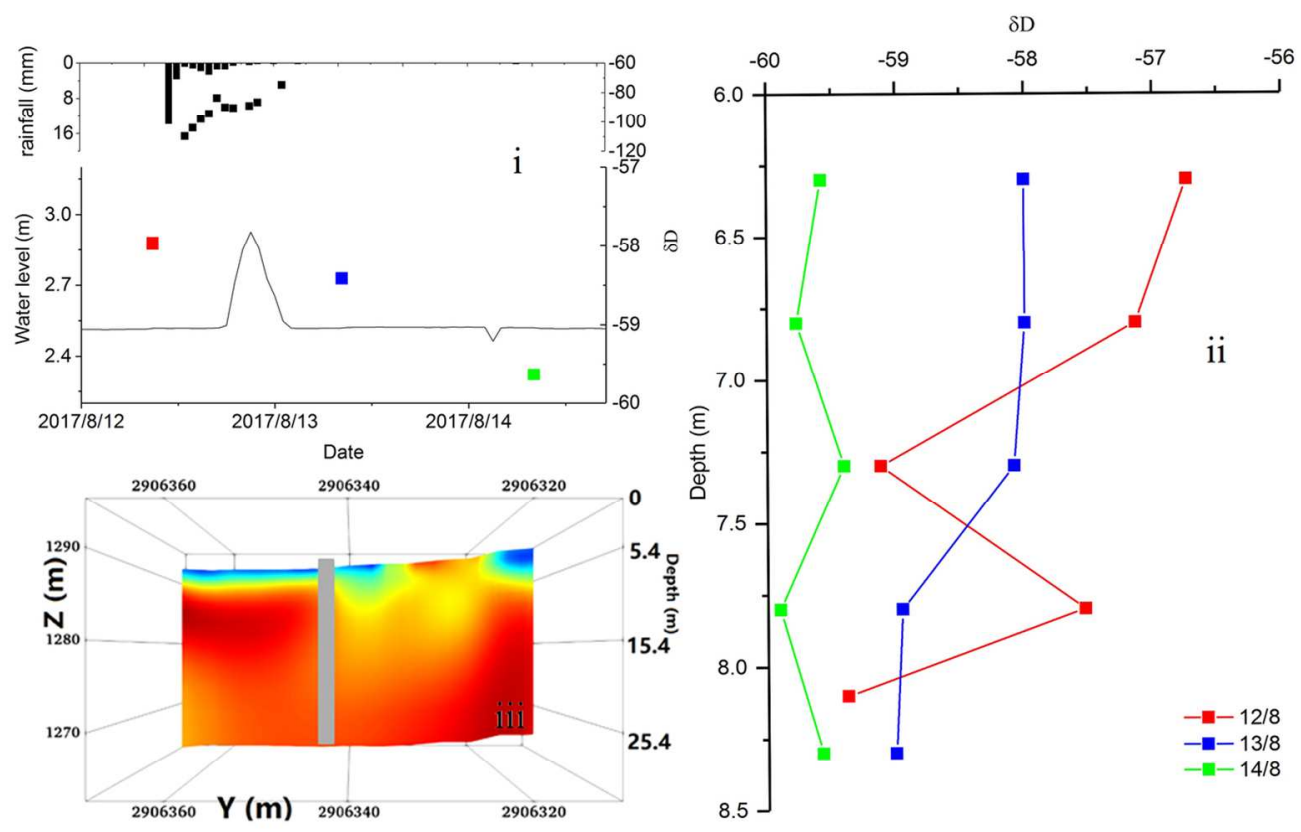

(d)

Figure 8 Variability of rainfall, water level and $\delta \mathrm{D}$ values (i), vertical distribution of groundwater $\delta \mathrm{D}$ values (ii) and ERT image (iii) of W1 (a), W3 (b), W4(c) and W5(d). The colour dots in the (i) plots are the mean $\delta D$ value of different depths.

$58 \times 40 \mathrm{~mm}(600 \times 600 \mathrm{DPI})$ 


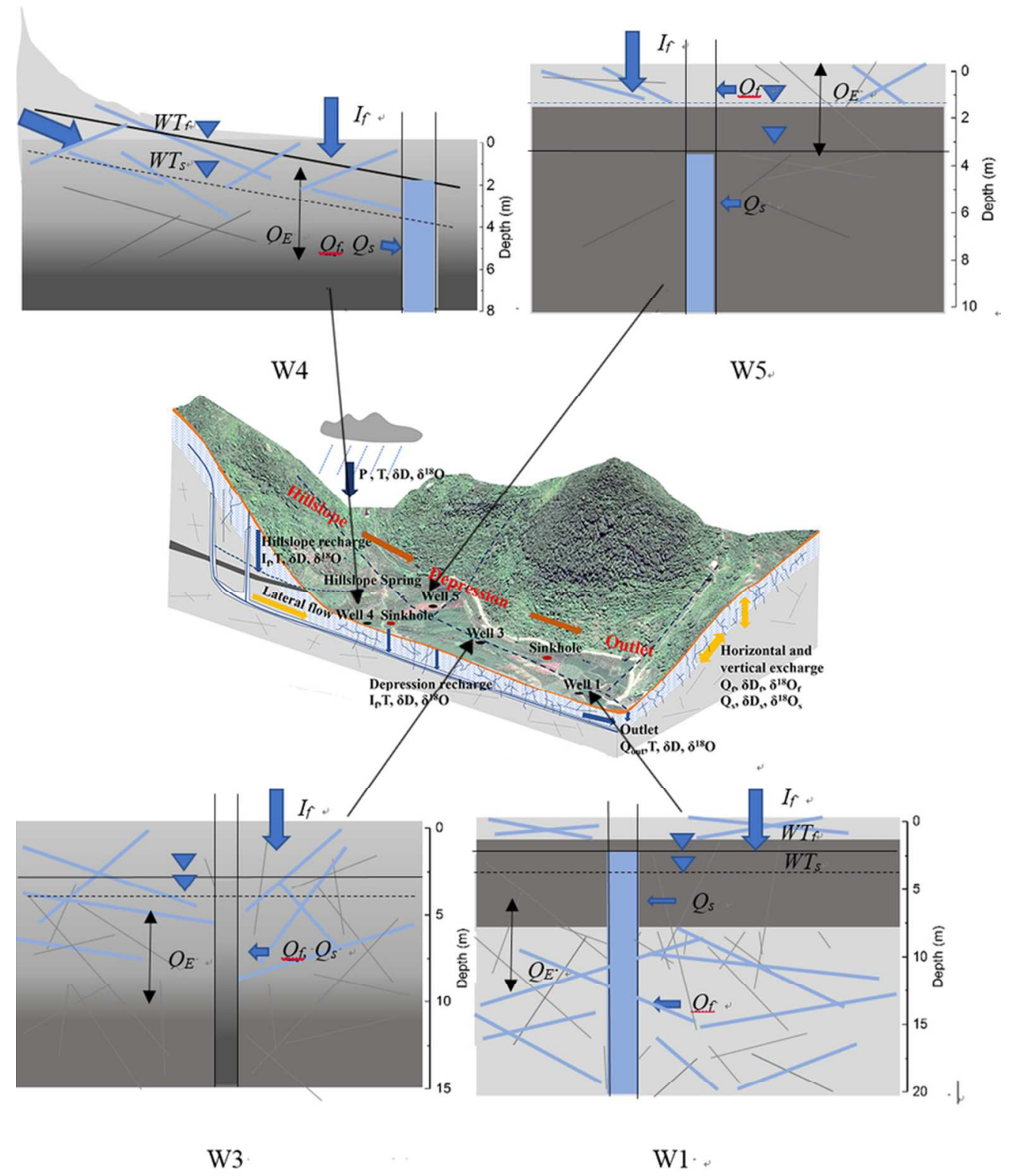

Figure 9 Conceptual model of groundwater aquifer at depression wells of W1, W3, W4 and W5. The high permeability layers in the grey color areas and low permeability layers in the deep grey color areas. WTf on solid lines is water table of fast flow reservoir, WTs on dotted lines is water table of slow flow reservoir, QE is exchange flow between fast (Qf) and slow flow (Qs) reservoirs and If is rainfall recharge.

$36 \times 43 \mathrm{~mm}(600 \times 600 \mathrm{DPI})$ 